NBER WORKING PAPER SERIES

\begin{abstract}
ARE WINDFALLS A CURSE? A NON-REPRESENTATIVE AGENT

MODEL OF THE CURRENT

ACCOUNT AND FISCAL POLICY
\end{abstract}

\author{
Aaron Tomell \\ Philip Lane
}

Working Paper No. 4839

\author{
NATIONAL BUREAU OF ECONOMIC RESEARCH \\ 1050 Massachusetts Avenue \\ Cambridge, MA 02138 \\ August 1994
}

We thank James Alt, Robert Barro, Olivier Blanchard, Richard Cooper, Anne Krueger, John Leahy, Mancur Olson, Jeffrey Sachs, Andrei Shleifer and Andres Velasco. All errors are our own. This paper is part of NBER's research program in International Finance and Macroeconomics. Any opinions expressed are those of the authors and not those of the National Bureau of Economic Research.

(C) 1994 by Aaron Tomell and Philip Lane. All rights reserved. Short sections of text, not to exceed two paragraphs, may be quoted without explicit permission provided that full credit, including (C) notice, is given to the source. 
NBER Working Paper \#4839

August 1994

\title{
ARE WINDFALLS A CURSE? A \\ NON-REPRESENTATTVE AGENT \\ MODEL OF THE CURRENT \\ ACCOUNT AND FISCAL POLICY
}

\begin{abstract}
$\underline{\text { ABSTRACT }}$
In several countries temporary terms of trade improvements have led to a deterioration of the current account. Furthermore, many of these countries failed to attain greater post-boom growth rates. The point we make is that the structure of the fiscal process is critical in determining outcomes. If fiscal control is unitary, then the consumption-smoothing effect is operative, and representative-agent models of the current account have predictive power. However, if control is divided among several fiscal claimants, a voracity effect appears which counteracts the consumption-smoothing effect, leading to a deterioration of the current account in response to a positive shock. We model the interaction among fiscal claimants as a dynamic game, and show that in equilibrium aggregate appropriation increases more than the windfall itself. This results in a deterioration of the current account. We also show that all the windfall is dissipated, with the country experiencing no increase in its growth rate. Lastly, we analyze the experiences of seven countries which have enjoyed large windfalls.
\end{abstract}

Aaron Tornell

Department of Economics

Littauer M-6

Harvard University

Cambridge, MA 02138

and NBER
Philip Lane

Department of Economics

Harvard University

Cambridge, MA 02138 


\section{Introduction}

An important prediction of representative-agent models of the current account is that a tenporary improvement in the terms of trade or in productivity leads to an improvement in the current account if the discount factor is constant. This result arises from the use of the current account as a consumption-smoothing device: dynamic optimization implies countries should accumulate foreign assets during a period of temporarily high output or terms of trade in order to maintain high consumption after the boom ${ }^{1}$.

The behaviour of several countries that have experienced major terms of trade shocks, however, does not conform with this prediction. Individual country studies recurrently describe apparently perverse adjustment to terms of trade gains ${ }^{2}$. A negative correlation also emerges in panel data regressions: in a sample of twenty-two countries which experienced large terms of trade shocks in the 1970s and 1980s, the average effect of a ternis of trade improvement on the current account over a five year period is significantly negative. ${ }^{3}$.

The negative correlation between the current account and the terms of trade could be made consistent with the consumption smoothing hypothesis if one assumes that all the shocks were expected to be permanent. However, this is difficult to justify because at least two of the largest shocks in the 1970s, as we argue below, were perceived to be temporary: the coffee shock of 1975 and the oil shock of 1979. The coffee boom was caused by a severe frost. which destroyed a big proportion of the coffee trees. The oil shock was caused by the Iranian revolution ${ }^{4}$.

The 1975 coffee shock generated a windfall for Cameroon equal to $9 \%$ of GDP during 1976-1979, and its current account improved by $4 \%$ of GDP, which is qualitatively what a representative-agent model would predict. Costa Rica and Cote d'Ivoire also enjoyed windfalls of $11 \%$ and $20 \%$ of GDP. In contrast to Cameroon, both countries managed to spend more than entire windfall: their current accounts deteriorated by $-1.7 \%$ and $-5.7 \%$ respectively.

Next we consider another anomaly. In many countries, fiscal policy, not private absorption, is the most important mechanism by which terms of trade shocks are transmitted to the current account. The windfalls led in several cases to conditions of fiscal euphoria in

\footnotetext{
'See Obstreld and Rogoff (1994), Razin (1993), Sachs (1982), Svensson and Razin (1983).

${ }^{2}$ See Gelb (1988), Cooper (1993), Gavin (1993), Little et al. (1993) and Pinto (1987).

${ }^{3}$ See Appendix C. The countries in the sample are those studied in the World Bank projects on terms of trade adjustment. See Gelb (1988) and Little et al. (1993).

${ }^{4}$ For the efffects of permanent shocks see Obstfeld (1982) and Glick and Rogoff (1992). However, Gavin (1993) argues that with irreversible investment, even if the positive shock has a large permanent conıponent, a smail amount of uncertainty should lead to a current account improvement.
} 
which the minister of finance was unable to stop the demands for greater fiscal resources from strong fiscal claimants. In these conditions constraints on public spending were relaxed, even to the extent that the increase in expenditure exceeded the size of the windfall itself.

A third anonaly is the failure of a number of countries to convert terms of trade gains into higher post-boom growth rates. Gelb (1988) and Little et al. (1993) attribute this to the fact that the windfalls were either consumed or invested in low return projects. Country studies describe how in many instances white elephant projects were undertaken, with systematic cost and time overruns, and how local leaders clamoured for federal revenues to be directed to inefficient local projects or used to finance consumption sprees that benefited their constituents and patronage networks 5 .

Summing up, the experiences of several countries that have enjoyed sizable terms of trade booms during the 1970s present three anomalies. First, in several countries terms of trade improvements led to a current account deterioration. Second, fiscal policy is typically the source of current account deterioration. Governments often manage to increase spending by a higher amount than the windfall itself, even when it is clear that the shock is temporary! Third, ternss of trade booms often do not raise growth rates: windfalls are frequently squandered in low return activities.

In this paper we develop a model of the current account which generates, in a setup of optimizing agents, the anomalies listed above. In the model government expenditure is the mechanism through which shocks are transmitted to the current account. The key difference with respect to traditional approaches is that fiscal policy is not determined by a benevolent social planner or some exogenous stochastic process. It is instead the outcome of a dynamic game among several infinitely-lived groups that have the power to appropriate resources from the national fiscal budget. In other respects, the model has a standard small open economy specification. The model reduces to a representative agent one if there exists just a single powerful fiscal group.

To fix ideas we will use the concept of "voracity". We define voracity as the proportion of public assets and of the tax base that strong fiscal claimants appropriate. These groups

\footnotetext{
${ }^{5}$ Murphy (1983) studies 1614 projects of $\$ 100$ million or more that were undertaken between 1970 and 1979 in 90 developing countries. She finds that 95 percent of the projects had a cost overrun of at least 100 percent, and 98 percent of projects had time overruns between 1 and 2 years. Kaufman (1991) uses data on economic rates of return (EER) after completion of 1200 projects financed by the World Bank and IFC during the 1970 s and 1980 s over 58 LDCs. Even for this closely supervised sample, he estimates that the likelihood of a negative ERR is 13 percent in countries with high "policy distortions," while it drops to 5 percent in low distortion countries. The likelihood of an ERR $<10$ percent is just 64 percent for high distortion countries, while it increases to 76 percent in low distortion countries.
} 
are spending ministries, provincial governments, state-owned enterprises [SOEs] and strong private corporations. Their claims are the financing of public investment projects, the underwriting of loans for private investment projects, increased public payrolls, and consumption and wage subsidies ${ }^{6}$.

The "voracity effect" is a more than proportional cbange in voracity, as defined above, in response to a shock. The voracity effect implies that if a shock generates a windfall of $x \%$ of GDP. then aggregate absorption increases by more than $x \%$ - even if the shock is perceived to be teniporary. As a result, current account deterioration takes place and a greater share of resources ends up used inefficiently. In other words, the windfall is a curse.

We make two points in this paper. First, in the presence of temporary productivity or terms of trade shocks, the consumption-smoothing hypothesis has predictive power only if there exists a unilary fiscal structure as in Indonesia under Suharto or Chile under Pinochet [see figure 1]. In this case the current account is positively correlated with the terms of trade. However, when there is divided control over the fiscal process, the voracity effect is also present. This effect counteracts the consumption-smoothing effect, inducing a decline in the current account in response to a temporary terms of trade improvement: two examples are Mexico in 1978-81 and Chile in the 1960s [see figure 1]. The second point we make is that under a divided fiscal process the squandering of the windfall is not a policy mistake. It is the equilibrium response of rational fiscal claimants who know that the windfall is temporary. ${ }^{7}$

Our argument is based on the observation that inefficient activities, such as unprofitable investment projects, are mechanisms which allow a fiscal claimant to appropriate public assets, and keep them safe from other strong groups. Such mechanism allow groups to store these assets in ways that make it impossible for other strong groups to appropriate them. These appropriated resources can be spent by the group at any time it desires -for its own benefit, to benefit its constituents, or for patronage purposes. One example is white elephant projects, many of which have built-in kickbacks that are deposited in secret bank accounts ${ }^{\mathbf{8}}$. Another is the appropriation of public assets for for pork-barrel projects or for programs

\footnotetext{
${ }^{6} \mathrm{It}$ is well documented that SOEs and provincial governments are important sources of pressure on fiscal policy [see Floyd et al. (1984) and Little et al. (1993)]. The ability of SOEs to extract resources from the fiscal budget derives in part from the fact that SOEs typically are required by politicians to achieve objectives unrelated to economic efficiency, such as the provision of employment for political supporters of the government or charging prices below cost on politically sensitive goods [see Shleifer and Vishny (1994)].

${ }^{7}$ A similar point is made by Blanchard, Lopez de Silanes, and Shleifer (forthcoming). They document how windfalls from lawsuits won by publicly traded firms were used by managers in ways that did not maximize shareholders' value.

the project, the better. Of course, one should not expect lots of documented evidence on this type of activity. Bangura (1987) provides some examples from Nigeria.
} 
Figure 1: Current Account and Government Spending Responses to Terms of Trade Shocks
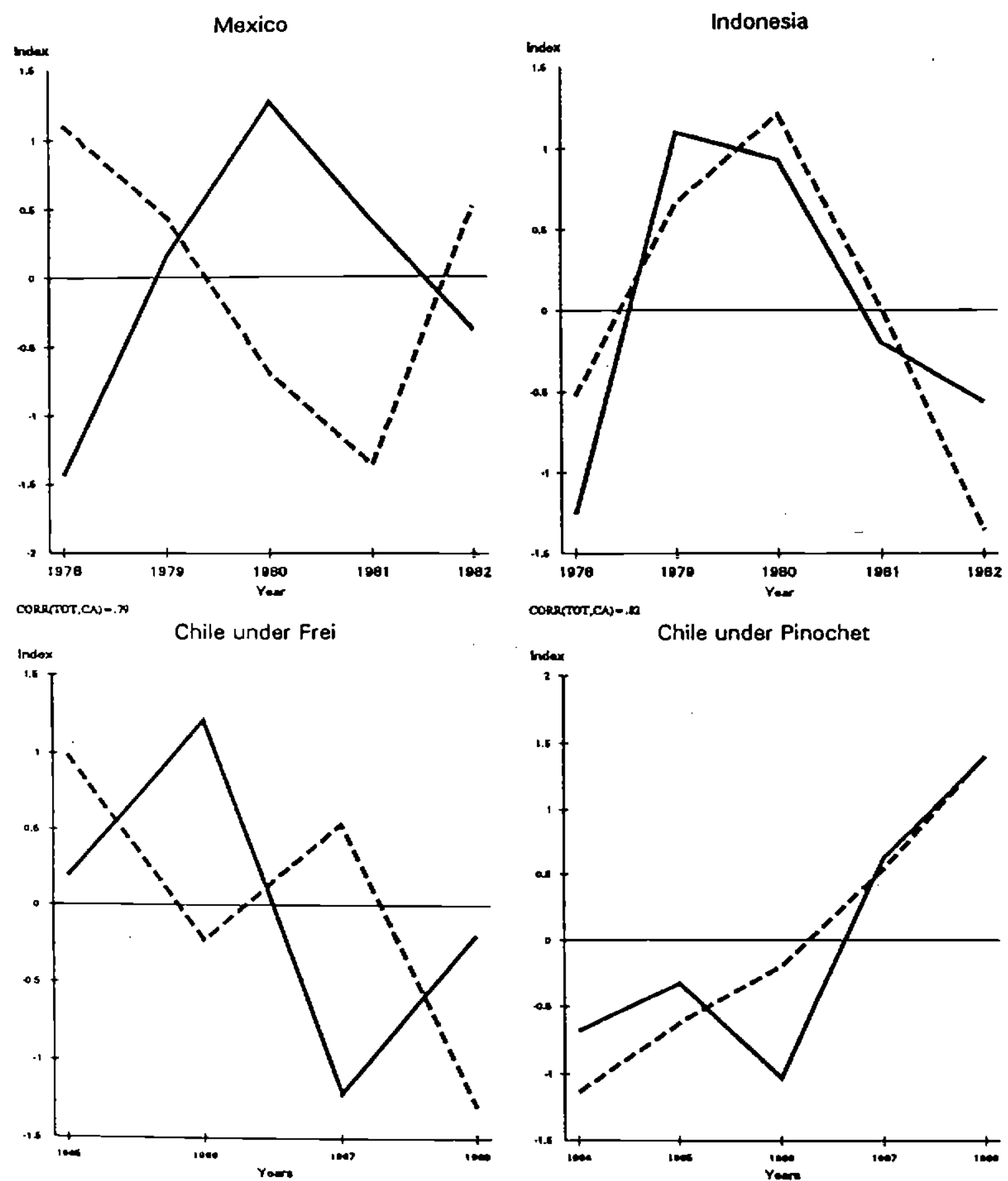

Chile under Pinochet

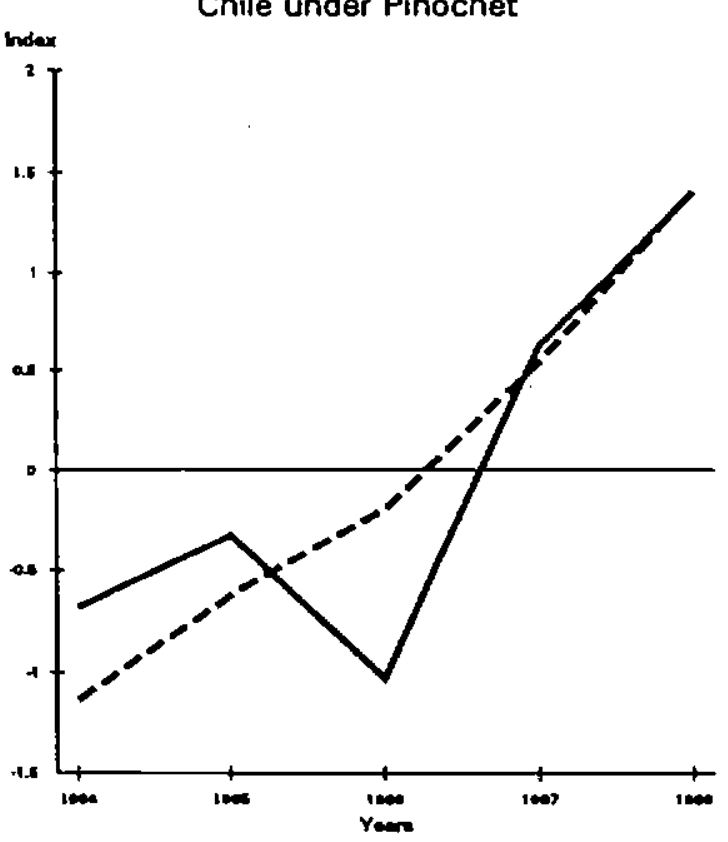

CORATTOT.CA) $=-16$

COPATTOT.CA) $=.67$

TOT - Torms of Trodo/GNP

CA $=$ Current Aocounz/GNP

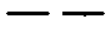

- For oach variablo, the index is: $X(1)=\mid X(t)-$ Mean $X \mid / 5 T$ TOV $X$

Source: Wond Toblos. Little of al. (1993). 
that generate unproductive jobs. Although socially inefficient, such programs insure a flow of funds to the constituents of the powerful group. The privileged receipients will have incentives to make donations and work hard in getting votes for the party. Indeed, if the strong fiscal claimant is booted from power in the future, the constituents would lose their unproductive jobs and pork-barrel contracts. ${ }^{9}$.

We formalize these ideas by assuming that powerful groups can accumulate wealth in two ways: by permitting growth in the stock of public assets, or by appropriating resources from the fiscal budget and saving via a private domain accumulation technology. The trade-off is that the private domain technology has a lower rate of return, but public assets suffer from a common pool problem in that they can be appropriated by other groups.

From the perspective of powerful groups as a whole, it is more efficient to let the central government invest any windfall and allocate to each group resources whenever it needs to make a transfer to its constituents. However, if there is common access to the fiscal budget, this is not an equilibrium because, like fishermen in unregulated waters, fiscal groups act opportunistically. A group that tries to conserve the stock of public assets by refraining from appropriation has no reason to believe it will gain from its sacrifice: the assets it has spared will be captured by some other group. On the contrary, if the group appropriates more public assets now it will be the richer for it. Although there will be fewer public assets in the future, the cost will not be borne by it alone, but shared among all the groups.

There are two possible outcomes. One is an all-out fiscal war, in which each group tries to appropriate what it can when it can. This will reduce the central government to a state of bankruptcy, in which all public assets are captured in the private turfs of the strong groups, yielding a very low return. The other is an outcome where each group limits its appropriation rate. Each group's appropriation rate will be just low enough to leave other groups indifferent between maintaining the status quo and starting an all-out fiscal war.

\footnotetext{
${ }^{9}$ The following quotes about Daley's Chicago and Cote d'Ivoire are revealing: "The third major part of the Machine is money... The money comes from countless sources. From the patronage army, it goes into the wards offices as dues, and part of it is turned into party headquarters... Contractors may be the biggest of all contributors. Daley's public works program has poured billions into their pockets, and they in turn have given millions back to the party in contributions. Much of it comes from contractors who are favored, despite the seemingly fair system of competitive bidding." (Royko, 197.., 74-75.). The following quote about Cote d'Ivoire is from Widner (1994, p.133): "...lobbying for local benefits and pork barrel projects remained primarily the preserve of a privileged few who had access to government decision making... Their purpose appears to have been to build followings that could be counted upon to move into the streets when the patron's power was challenged. Such local benefits went primarily to the home areas of the President, the party chief..., army chief..., and the Coulibaly family. Despite complaints..., many other regional capitals were underfunded and without basic services."
} 
A positive shock, by increasing national income, increases tax revenue and hence the "raw" growth rate of public assets. The relaxation of the common budget constraint induces each fiscal clainualut to increase its appropriation rate from the national budget with the knowledge that increased appropriation is now feasible without provoking other groups to start an all-out fiscal war. In section 3 we show that it is not an equilibrium outcome for everyone to simply split the windfall. In a Markov perfect equilibrium aggregate appropriation must increase by more than the windfall [this is the voracity effect]. This surprising result means that the windfall induces a decline in the growth rate of net public assets. Since these are internationally tradeable, a current account deterioration results. Although the private sector behaves optimally in our model, private consumption does not react to the shock because the government captures all the gains from the terms of trade improvement through taxation. The response of the private sector is limited to an asset reallocation between home and foreign assets ${ }^{10}$.

We also show that all the gains from the windfall are dissipated. The positive shock does not lead to an increase in the growth rate of the economy, nor to an increase in welfare: as aggregate appropriation out of public assets grows more than the windfall, a greater share of resources ends up allocated to low return activities. This reduces the average growth rate in the cconomy. In equilibrium the increase in the raw growth rate of public assets is completely counteracted by this asset reallocation".

In section 4, we present the experiences of some countries which had large temporary terms of trade improvements and provide evidence supporting the setup and results of our inodel. We show that fiscal structures vary importantly across countries and are critical in country adjustment to terms of trade disturbances. In addition, we give examples of investment projects where squandering occurred, in order to illustrate the mechanism by which fiscal claimants appropriate public assets. The events studied are the 1975-79 coffee shock, the 1979-82 oil shock, and the Chilean adjustment to copper price fluctuations. The Chilean case is interesting because Chile underwent a dramatic shift in its policymaking

\footnotetext{
${ }^{10}$ In the presence of temporary shocks, a negative correlation between the current account and the terms of trade can also be generated in a representative-agent model if the real discount factor is variable [for instance, if there are non-traded goods]. See Dornbusch (1983) and Svenseon and Raxin (1983).

"We consider a dynamic model where fiscal appropriations vary in response to shocks instead of a setup where the government simply spends all it can when it can because, in the latter setup, one could not speak about an increase in voracity [i.e. an increase in the proportion of public assets appropriated by fiscal claimants]. In such a setup appropriation would be maximised during every period anyway. Therefore, one could not explain the anomalies mentioned above, which depend crucially on changes in the appropriation rate. Moreover, if the government were to appropriate all it could when it could, it would be troublesome to even speak of a current account.
} 
regime [from divided to unitary] in the 1970s.

We choose a sample of countries for which there is consensus in the literature concerning the structure of the fiscal system ${ }^{12}$. For the coffee boom, we studied Cameroon, Costa Rica and Cote d'Ivoire. For the 1979-82 oil shock, we studied Indonesia, Mexico and Nigeria. We find that adjustment to terms of trade shocks appears to depend on fiscal structure. As can be seen in tables 1 and 2, Cameroon, Indonesia and Chile under Pinochet, all of which possessed unitary fiscal regimes, saved the windfalls. In contrast, Costa Rica, Cote d'Ivoire, Mexico, Nigeria and Chile unde Frei, all of which had divided fiscal processes, fell victim to fiscal euphoria and suffered current account deteriorations. As can be seen in table 3 , the former set of countries experienced higher growth rates than the latter in the years following the positive shock.

Nigeria is a clear example of a country which wasted its windfall, as witnessed by negative growth in the post-boom period. In nominal terms, Nigeria's exports increased from $\$ 12$ billion in 1978 to $\$ 28$ billion in 1980 . By 1982 , they reverted to $\$ 13$ billion. Unresolved regional tensions during the oil boom led to intense competition among state governments for federal resources: one outcome was the duplication of investment projects, with large scale steel mills being constructed in both Ajaokuta and Aladja regions. The estimated cost of each plant was $\$ 1$ billion. However, the costs turned out to be $\$ 4$ and $\$ 2$ billion respectively. One estimate puts the cost of corruption associated with Nigerian public investment at 75 percent of the total cost of each project [see Bangura (1987)]. None of the plants has operated at more than 25 percent capacity.

The structure of the paper is as follows. In Section 2, we present an overview of the model. In section 3 the model is laid out and the results are derived. Section 4 presents some case studies. Section 5 concludes.

\section{Overview of the Model}

We extend a simple representative-agent model of the current account to allow for the existence of inultiple fiscal claimants. The model is a differential game among fiscal claimants. We solve for the interior Markov perfect equilibrium of this game, and obtain in closed-form the path of fiscal appropriations, net public assets and the current account.

The economy is composed of a government and a private sector. The government is formed by $n$ groups that can extract resources from the fiscal budget. These groups share a cummon constraint, which is the standard government budget constraint that the present

\footnotetext{
${ }^{12}$ Nominal measures of fiscal structure, such as federalism or dictatorship, do not have predictive power.
} 
value of spending be no more than the present value of tax revenue plus the value of publiclyowned assets. As noted in the introduction, each group is also able to accumulate its own assets to which other groups do not have access. As examples, a parastatal firm may invest in extra plant capacity or a provincial government in local infrastructure.

Groups are infinitely lived. Every period, each one must choose the amount it will appropriate from the common pool, and out of this what to spend (to benefit constituents) and what to save in its private domain technology. To capture the porkbarrel nature of such investment projects, we assume that the raw (i.e. pre-appropriation) rate of return on commonly-held public assets is greater than the rate of return on the private domain accumulation technology available to fiscal claimants. Given the superior rate of return on commonly-held public assets, there exist two Markov perfect equilibria. In the extreme equilibrium, there is an all-out fiscal war in which every group appropriates as much public assets as it can. In the other equilibrium, each group limits its appropriation rate. In the interior equilibrium, each group sets its appropriation rate so that the post-appropriation return on commonly-held assets is equal to the rate of return offered by the private domain storage technology:

Suppose now that there is an improvement in the terms of trade that expands national income and tax revenue. This increases the raw growth rate of public assets [i.e. the preappropriation rate of return]. With a higher pre-appropriation public rate of return, a given group can now increase its appropriation rate and still leave others with a post-appropriation rate of return which is equal to the rate of return on their private technology. In equilibrium, all of the $n$ groups take advantage of this opportunity. We show in section 3 that the increase in aggregate appropriation must exceed the size of the windfall. This reduces the growth rate of public assets during the period of the boom, regardless of whether it is temporary or permanent. As noted above, we term this the voracity effect.

The private sector is composed of a representative agent that can invest at home and abroad. The government does not maximize the welfare of the representative consumer, but rather it maximizes tax revenue ${ }^{13}$. In response to positive shocks to the terms of trade, it increases the tax rate in order to capture all the gains and, conversely, reduces the tax rate in the face of negative shocks. This implies that the private consumption path is unaffected by shocks. Hence, domestic investment is the only channel through which the private sector affects the current account: the stock of domestic private capital changes with movements in the stock of public assets, as domestic investors take into account the risk of capital levies.

\footnotetext{
${ }^{13}$ Levy (1988) argues that historically this has been the objective of governments. She presents evidence from Rome, England and France.
} 
Given this specification of the taxation system, the effects of a shock to the terms of trade are channeled through changes in public asset accumulation. Thus, in our model an improvement in the terms of trade induces a deterioration of the current account because aggregate appropriation increases more than the windfall itself. This result stands in sharp contrast to the predictions of representative-agent models of the current account (with constant discount factors), in the case of temporary shocks.

We also show that all the benefits of the windfall evaporate. The positive shock does not. lead to a higher growth rate and there is a welfare gain neither for the economy nor any liscal group. This is because the positive shock exacerbates the distributive struggle (the voracity effect), inducing a greater share of assets to be held privately by powerful groups. This reduces the average rate of return in the economy. We show that in equilibrium this loss equals the original windfall ${ }^{14}$.

Another result of our analysis is that the voracity effect is nonlinear in the number of groups with access to fiscal resources. If $n=2$, that is fiscal power is evenly split between two powerful groups, the voracity effect is maximised. If $n>2$, the voracity effect is mitigated.

\section{The Model}

We consider an economy composed of a public sector and a private sector. We start by describing the public sector. It consists of $n$ groups that have the power to appropriate fiscal resources. Each group derives utility from the public expenditures it realizes $d_{i}(t)$. These expenditures include publicly-provided goods and services, government payrolls, production and consumption subsidies and direct income transfers. The powerful groups include spending ministries, provincial governments, labor unions, trade associations and members of the legislature, amongst others. These groups do not maximize the representative consumer's

\footnotetext{
${ }^{14}$ It might be argued that short-term horizons on the part of policymakers importantly contribute to the fiscal euphoria phenomenon we are interested in. This consideration is in fact not fundamental. One interpretation of our model is that power alternates smong different groups. When in power, a group has complete autonomy over fiscal policy. A group that knows it will be replaced, although it has the possibility to appropiate as much as possible while it is in power, does not do so. Its appropriation will be limited by the knowledge that, even if it is replaced, it may return to power at some future date and hence the group will want to maintain some stock of public assets, given that the raw rate of return on public assets exceeds that on privately-held resources. This "alternating governments" game is similar to the one that we study in this paper. Perotti (1993) analyzes the current account in a setting in which fiscal policy is determined by voting among income classes enjoying different degrees of international mobility.
} 
welfare as in the standard models. The objective function of group $\mathrm{i}$ is

$$
\int_{0}^{\infty} \frac{\sigma}{\sigma-1} d_{i}(t)^{\frac{\sigma-1}{\sigma}} e^{-\delta t} d t
$$

We can think of this objective function as reflecting the benefits to a powerful group of providing transfers to its constituents. These benefits to the powerful group might take the form of votes or direct bribes. For simplicity, in the model we identify these benefits with the utility flows enjoyed by private agents as given by (6) below.

Next we describe the budget constraints of the powerful groups. Each group has access to aggregate fiscal resources, in the sense that during each instant, it can appropriate up to a proportion $\bar{x}$ of aggregate fiscal assets. Note that, unlike the representative agent case, the expenditures of each group need not match its fiscal appropriations period by period, when there are inultiple groups sharing a common pool. It is only over the long run that these decisions are linked. This is because a group may find it optimal to appropiate some amount of public assets in a given period, given that commonly-held assets are open to appropriation by other groups. However, it may suit the group to store its appropriation privately and spend at a later date. In the representative-agent case these decisions are identical because there is no danger that others will consume what the group does not appropiate.

This delinking captures the way in which several fiscal systems work. For instance, in some systems provinces and state-owned enterprises maintain separate balance sheets and, by issuing bonds or investing surplus resources, are free to determine the timing of their expenditures independently of the arrival of resources from the center. A second instance is that of a fiscal group appropiating resources to purchase some durable good providing a stream of benefits and being free to determine its depletion rate over time.

We formalize these ideas by assuming that the amount appropriated by group $i$ at time t $g_{1}(t)$ need not be equal to its expenditure $d_{i}(t)$. If there is a surplus of $g_{i}(t)$ over $d_{i}(t)$, it can be safely stored by group i. It follows that the budget constraints faced by each group are the aggregate public sector constraint

$$
\dot{A}(t)=\alpha A(t)+T(t)-\Sigma_{i=1}^{n} g_{i}(t)
$$

and the group's private assets accumulation equation

$$
\dot{B}_{i}(t)=\beta B_{i}(t)+g_{i}(t)-d_{i}(t)
$$

In addition $A(t)$ and $B_{\mathrm{i}}(t)$ must satisfy the following constraints

$$
A(t) \geq 0, \quad B_{i}(t) \geq \underline{B}
$$


where $\underline{B}<0$ is possible. Note that if there is only one agent with the power to assign appropriations to the $n$ groups, then appropriation is set equal to expenditure period by period. The problem then reduces to a representative government model. We consider this case in subsection 3.2 .

In equation(2), $T(t)$ is tax revenue, and $A(t)$ is the stock of net public assets. $A(t)$ is internationally tradeable and it has a rate of return $\alpha$ in terms of the importable good. $B_{i}(t)$ are the net assets privately held by group $i$, in the sense that no other group has access to them. $B_{i}$ consists of non-internationally tradeable assets. As discussed earlier $B_{i}$ may include SOEs, assets of provincial governments, unexercised claims on the central budget or dirty and hidden money.

As discussed in the introduction, $B_{i}(t)$ represents inefficient investments relative to letting the national fiscal authority accumulate internationally tradeable assets or leaving resources in the hands of the private sector until transfers are actually made. They are socially inefficient mechanisms to transfer public assets to the private domain of strong groups. To capture this idea we assume that

$$
0<\beta<\alpha
$$

Now we describe the private sector and derive the tax revenue function. The representative private agent derives utility from consumption and from the public services it receives

$$
\int_{0}^{\infty}\left[\frac{\sigma}{\sigma-1} c(t)^{\frac{\sigma-1}{\sigma}}+\sum_{i=1}^{n} \frac{\sigma}{\sigma-1} d_{i}(t)^{\frac{\alpha-1}{\sigma}}\right] e^{-\delta t} d t
$$

The private agent has two investment opportunities available. It can invest abroad and receive an after-tax rate of return $f$, or it can invest domestically, producing an export good with a linear technology. It follows that its accumulation equation is

$$
\dot{W}(t)=[1-\tau(t)] p(t) k(t)+f[W(t)-k(t)]-c(t) \equiv Y(t)-c(t)
$$

where $W(t)$ are total private assets, and $k(t)$ are private assets invested domestically. Private assets can be costlessly and instantaneously transferred to and from abroad ${ }^{15}$. The private agent chooses sequences $\{k(t)\}$ and $\{c(t)\}$ in order to maximize (6) subject to (7) and the tax policy of the government.

Recall that the government we are considering is not a benevolent one that maximizes social welfare. We assume that the fiscal authority maximizes the present value of fiscal

\footnotetext{
${ }^{15}$ In some models of the current account there are adjustment costs to investment: see Matsuyama (1987), Razin (1993) and Obstfeld and Rogoff (1994). Incorporating adjustment costs into our model would not provide additional insight into the fiscal mechanism we are interested in.
} 
revenue. The fiscal authority can tax domestic production at any rate it desires and it can expropriate the entire stock of capital held domestically. However, it cannot tax foreign source income. In this setup the fiscal authority will increase the tax rate in response to a positive shock in order to capture all the gains. Conversely, in the face of a negative shock it will reduce the tax rate. This implies that the response to shocks will be channeled through the government sector, not through private agents.

Given this revenue-maximising behaviour, the voracity effect described above and the ability of private domestic agents to invest abroad, we will show in the remainder of this subsection that the equilibrium tax revenue function $T(A, p)$ is extremely simple and has the following properties: $T_{A}>0, T_{p}>0, T_{A p}>0$, where $p(t)$ is the price of the export good in terms of the consumption good [i.e. the terms of trade]. The signs of the derivatives are intuitive: a wealthier government [high $A(t)$ ] will be less likely to expropriate private capital because it can be more easily punished. Thus, more domestic investment takes place, increasing the tax base. Holding fixed the wealth of the government, an increase in the terms of trade or in productivity raises the attractiveness of domestic investment, which again implies an increasing tax base.

During each instant the timing is as follows. First, $p(t)$ is revealed. Second, the tax authority announces and commits to a tax rate $\tau(t)$. Third, the private sector chooses $k(l)$. Fourth, the government decides whether to expropriate the entire stock of $k(t)$. As it is a commonly assumed in the international debt literature, if there is expropriation, the government is forced by the international community to repay to the private sector $\min [k(l), 0 . A(l)\}^{15}$.

Since there are no adjustment costs, private agents choose during each instant $k(t)$ to naximize $Y(t)$ in $(7)$. Therefore,

$$
k^{*}(t)=\left\{\begin{array}{cc}
\theta A(t) & \text { if }[1-\tau(t)] p(t) \geq f \\
0 & \text { otherwise }
\end{array}\right.
$$

We assume that the economy is sufficiently productive, so that for any realization of $p(t)$, $k(l)>0$ if $\tau(t)=0$

$$
p(t) \geq p>f>0
$$

where $p$ is a constant. It follows from (8) and (9) that the tax rate that maximizes the

\footnotetext{
${ }^{16}$ See Eaton (1993), Cohen and Sachs (1986). Typically, in these models the game is between a government and international banks. Here the game is between the government and private (international) investors.
} 
present value of tax revenue is

$$
\tau^{*}(p(t))=1-\frac{f}{p(t)}
$$

Since fiscal revenue is $\tau p k$, using (8) and (10) we have that

$$
T^{*}(p(t), A(t))=\theta[p(t)-f] A(t)
$$

The basic point of equation (11) is that fiscal revenue is increasing in $A(t)$, and that this relation becomes steeper at higher $p(t)^{17}$. Substituting (11) in (2) we have that

$$
\left.\dot{A}(t)=r(p(t))-\sum_{i=1}^{n} g_{i}(t), \quad r(p(t)) \equiv \alpha+\theta[p(t)-f]\right]
$$

where $r(p(t))>0$ is the total rate of return faced by the public sector.

To finalize the description of the economy we specify the process followed by $p(t)$. We consider the following process

$$
p(t)=\left\{\begin{array}{cc}
p \text { for } & t<t_{1} \text { and } t \geq t_{2} \\
p+\epsilon \text { for } & t \in\left[t_{1}, t_{2}\right)
\end{array}\right.
$$

A permanent shock corresponds to $t_{2}=\infty$. The information set of all agents is the following. At any $t<t_{1}$ everyone expects $p(t)=p$ for all $\mathrm{t}$. At $t=t_{1}$ an unexpected shock takes place and everyone learns the values of $\epsilon$ and of $t_{2}{ }^{18}$.

In the remainder of this section we will show that in the divided government case any positive shock, regardless of whether it is permanent or temporary, leads to a deterioration of the current account in the short run. We will contrast this result with the representative agent case, in which positive temporary shocks lead to improvement in the current account.

\subsection{The Divided Government Case}

In this case each group chooses sequences $\left\{g_{i}\right\}$ and $\left\{d_{i}\right\}$ in order to maximize (1) subject to $(3),(4),(12),(13)$, the strategies followed by the other groups, and

$$
0 \leq g_{i}(t) \leq \tilde{x} A(t), \frac{r(p)+\theta \epsilon-\beta}{n-1}<\bar{x} \leq 1
$$

\footnotetext{
${ }^{1}$ If instead of setting $\tau(t)$ optimally we restricted it to be a constant, the tax revenue function would have the same properties as (11): $T_{p}>0, T_{A}>0, T_{A p}>0$.

${ }^{18}$ The analysis in what follows holds equally well for multiplicative productivity shocks as for terms of trade shocks. For simplicity, we just refer generically to terms of trade disturbances.
} 
$\bar{x} A(t)$ is the upper bound on the appropriation each group can make. We bave set the lower bound on $\bar{x}$ sufficiently high so that (14) is not binding in equilibrium. In addition we impose the following restrictions on parameters

$$
z(\beta)>0, \quad n<1+[r(p)-\beta] / z(\beta)
$$

Throughout the paper we will repeatedly use the expression $z$. For any variable $X, z(X)$ is defined as

$$
z(X) \equiv X[1-\sigma]+\delta \sigma
$$

We show in Appendix A that $z(\beta)>0$ is necessary for the value function to be bounded. Note that if $\sigma=1$, this condition reduces to the familiar condition $\delta>0$. The second condition is necessary and sufficient for the $B_{i}(t)$ 's to be increasing along the equilibrium path. This insures that constraint (4) is not binding along the equilibrium path.

Groups choose their appropriation rates in a noncooperative manner. We assume that groups cannot coordinate and attain the efficient outcome, which is not to use the private technologies (3), as the Coase Theorem would suggest.

The problem described above is a differential game. The solution concept we will use is Markov Perfect equilibrium. A strategy of group $i$ consists of an appropriation policy and an expenditure policy. A strategy is Markov if it is a function solely of the realization of the state. An n-tuple of strategies forms a Markov Perfect equilibrium if they are best responses to each other at every realization of the state [Maskin and Tirole (1988)]. In this model the state has $n+2$ elements $\left\{p(t), A(t), B_{1}(t), \ldots, B_{n}(t)\right\}$.

We show in appendix $A$ that there is a unique interior Markov perfect equilibrium in this game, i.e., one where $g_{i}(t)<\bar{x} A(t)$ for all $i$. In order to characterize it we will find $n$ strategies, one for each group: $\left(\left\{d_{i}(t)\right\},\left\{g_{i}(t)\right\}\right)$, with the property that starting at each instant, strategy $i$ maximizes the payoff of group $i$, taking as given the strategies of the other nl-1 groups, and subject to (3), (4), (12) and (14). Since we are restricting strategies to be Markov, we can find the equilibrium as the solution to a set of $\mathbf{n}$ Hamiltonian problems. This is done in Appendix $A$ by taking the following steps: when solving for the strategy of group i we postulate $g_{-i}^{*}(t)=x_{-i}^{*}(p(t)) A(t)$, with $x_{-i}^{*}(p(t))$ an unknown piecewise continuous function. We then determine endogenously the $x_{i}^{*}$ 's and the $d_{i}^{*}$ 's. Lastly, we show that the solution we found is the unique interior equilibrium. 
In the interior equilibrium

$$
\begin{gathered}
g_{i}^{*}(t)=x^{*}(r(p(t))) A(t)=\frac{r(p(t))-\beta}{n-1} A(t) \\
d_{i}^{*}(t)=z(\beta)\left[A(t)+B_{i}(t)\right]=z(\beta)\left[A(0)+B_{i}(0)\right] e^{[\beta-\delta] \sigma t} \\
A^{*}(t)=\left\{\begin{array}{c}
A(0) \exp \left(\frac{n \beta-r(p)}{n-1} t\right) t<t_{1} \\
A\left(t_{1}\right) \exp \left(\frac{n \beta-\alpha-\theta_{c}}{n-1}\left[t-t_{1}\right]\right) t \in\left[t_{1}, t_{2}\right) \\
A\left(t_{2}\right) \exp \left(\frac{n \beta-r(p)}{n-1}\left[t-t_{2}\right]\right) t \geq t_{2}
\end{array}\right. \\
B_{i}^{*}\left(t_{i} s_{h}\right)=\left\{\begin{array}{c}
\left.A\left(s_{h}\right)+B_{i}\left(s_{h}\right)\right] e^{\sigma[\beta-\delta]\left[t-s_{h}\right]}-A(t), t \in\left[s_{h}, s_{h+1}\right) \\
h=\{0,1,2,3\} s_{0}=0, s_{1}=t_{1}, s_{2}=t_{2}, s_{3}=\infty
\end{array}\right.
\end{gathered}
$$

The intuition behind this result is as follows. Suppose that group $\mathrm{i}$ owns the entire stock $A(t)$, and that each of the other groups sets $g_{j}(t)=x_{j}(r(p(t))) A(t)$, with $x_{j}(r(p(t)))$ an unknown function. It follows that $i$ 's perceived rate of return on $A(t)$ is $r(p(t))-\Sigma_{j \neq i} x_{j}(r(p(t)))$. During each instant group $i$ must decide how to allocate its wealth between $A(t)$ and $B_{i}(t)$. In order for $\mathrm{i}$ to set $x_{i}(r(p(t)))<\bar{x}$, it is necessary that the rate of return on i's private technology $\beta$ be equal to $i$ 's rate of return on $A(t)$ after appropriation by other groups. This implies that the following condition must hold for any $i$ in an interior equilibrium

$$
\beta=r(p(t)))-\Sigma_{j \neq i} x_{j}(r(p(t))), i=1, \ldots, n
$$

Note that this condition holds simultaneously for all $\mathrm{i}$, if and only if, all $x_{j}(r(p(t)))$ 's are identical and are given by $x^{*}(r(p(t)))$ in (16).

We turn now to $A(t)$. It is derived by substituting (16) in (12). Since $x_{i}^{*}(p(t))$ in (16) does not depend on the future realizations of $p(t)$, it follows that for $t<t_{1}$ the evolution of $A(t)$ in (18) does not depend on whether the shock to $p(t)$ is anticipated and, for $t \in\left[t_{1}, t_{2}\right)$, it is independent of the duration of the shock (permanent or temporary). Therefore, it follows from (18) that a positive shock to productivity or to the terms of trade whether expected or unexpected, temporary or permanent, has the effect of reducing the growth rate of net public assets. Namely

$$
\frac{\partial \dot{A}(t) / A(t)}{\partial \epsilon}=\frac{-\theta}{n-1}<0 \text { for } t_{1} \leq t<t_{2}
$$


Note that not only does the growth rate of $A(t)$ fall, but for sufficiently large $\epsilon$ it becomes negative during the period $\left[t_{1}, t_{2}\right)$.

This result comes from the voracity effect: if I save the windfall, she will grab it. The intuition is as follows. The higher $r(p(t))$ leads to an increase in the raw growth rate of net public assets (i.e., before appropriation by other groups). As $r(p(t))$ goes up, each group can afford to be more voracious and still leave the other groups with a post-appropriation rate of return on net public assets equal to $\beta$. However, in the aggregate this leads to a grealer increase in the appropriation rate than the original increase in fiscal revenue. This is an instance of a dynamic externality in a common pool context. Hence, ex-post the positive shock leaves public finances in a worse shape!

This result is at the heart of the paper. The mechanism by which this perverse outcome occurs is as follows. Note that the raw [i.e. pre-appropriation] rate of return goes up by $\Delta r\left(t_{1}\right)=\theta \epsilon$ when the shock occurs. This increase in the raw rate of return represents an opportunity for some group to increase its appropriation rate without reducing, below $\beta$ the post-appropriation rate of return faced by other groups. In equilibrium, every group increases its appropriation rate by this reasoning and the size of the individual increase, from equation (16), is given by $\Delta r\left(p\left(t_{1}\right)\right) \frac{1}{n-1}$. This lack of coordination implies that the aggregate appropriation rate increases by $\Delta r\left(p\left(t_{1}\right)\right) \frac{n}{n-1}$ which is greater than $\Delta r\left(p\left(t_{1}\right)\right)$. As a result the growtl 1 rate of net public assets falls: $\Delta \dot{A} / A=\Delta r-\Delta r n /[n-1]=-\theta \epsilon /[n-1]$. In this sense, then, a positive shock results in a deterioration in the state of the public finances.

An interesting feature of the model, which follows from (20), is that starting from $n=2$ as we increase the number of groups, the negative effect of an increase in $r(p(t))$ on $\dot{A}(t)$ becomes smaller. With more groups, each one increases its appropriation rate by less as $r$ goes up. Moreover, individual appropriation declines at a faster rate than the number of groups. Therefore, the aggregate appropriation rate declines with the number of groups for $n>2$. An analogous result pertaining to the number of unions involved in wage-setting obtains in Alesina and Perotti [1994].

Next we consider the intuition behind $d_{i}^{*}$ and $B_{i}^{*}$. Regardless of how each group distributes its resources between the common and the private technology, it faces a rate of return $\beta$ in equilibrium. Consequently, as in the representative agent model, its expenditure grows at the constant rate $\sigma[\beta-\delta]$, where $\sigma$ is the elasticity of intertemporal substitution and $\delta$ is the discount rate. What is surprising about (17) is that $d_{i}^{*}(t)$ does not jump when the unexpected shock occurs at $t_{1}$. Moreover, the expenditure path is independent of shocks to $p$. This is because an increase in $p$ leads to a greater appropriation rate (the voracity effect). This induces a lower intensity in the use of the public technology and a greater intensity in 
the use of the private inefficient technologies. This shift in resources implies efficiency losses from a social perspective. In equilibrium this loss in aggregate efficiency turns out to equal the original gain induced by the increase in $p$. Using different terms, on the interval $\left[t_{1}, t_{2}\right)$ $A^{*}(t)+B_{i}^{*}(t)$ is independent of the path followed by $p(t)$. To see this add up (18) and (19) to get $A^{*}(t)+B_{i}^{*}(t)=\left[A\left(t_{1}\right)+B_{i}\left(t_{1}\right)\right] e^{\sigma[\beta-\sigma]\left[t-t_{1}\right]}$, and note that it is independent of the path of $p(t)$. The intensification of the voracity effect exactly cancels the direct effect of the windfall and the aggregate growth rate fails to increase.

One can also show that the improvement in the terms of trade does not generate any welfare gains. By substituting (17) in (1), we have that for any path of the terms of trade that satisfies (9), the payoff of group $i$ is given by

$$
J_{i}\left(A(0)+B_{i}(0)\right)=\frac{\sigma}{\sigma-1}\left[A(0)+B_{i}(0)\right]^{\frac{\sigma-1}{\sigma} z(\beta)^{-\frac{1}{\sigma}}}
$$

Equation (2l) states that the welfare of each group, and hence social welfare, is not affected by the path of the terms of trade ${ }^{19}$. From a theoretical perspective this might be a surprising result. However, it is consistent with the finding of Gelb (1988) and Little et al. (1993) that many countries squander terms of trade windfalls. We summarize the results of this subsection in the following proposition

\section{Proposition 1}

- If public expenditure is determined in a non-cooperative fashion, then a positive shock to productivity or the terms of trade, whether temporary or permanent, leads to a fall in the growth rate of net public assets. Moreover, this growth rate becomes negative for a sufficiently high shock.

- The fall in the growtl rate of net public assets is greatest when there are two powerful groups with access to fiscal revenue.

- All the benefits of the windfall are dissipated: the growth rate of the economy does not increase, and the welfare of each powerful group (and social welfare) remain unchanged.

The first part of proposition 1 applies to either a temporary or a permanent shock because in a Markov Perfect equilibrium, strategies depend only on the current realization of the state. Thus, the appropriation rate at time $t$ and $d A^{*}(t) / d t$ are just a functions of $p(t)$ as can be seen in (16) and (18).

\footnotetext{
${ }^{19}$ With a fixed tax rate, welfare of powerful groups would remain constant, but the private sector would enjoy increased welfare.
} 


\subsection{The Unitary Government Case $(n=1)$}

This case occurs when there exists only one agent with the power to allocate expenditures among the $n$ groups, or when all powerful groups determine fiscal policy in a cooperative way. We shall show that in this case predictions analogous to those of the representative agent model of the current account hold. In this case, tecbnology (3) is dominated by technology (12) because $r(p(t))>\beta$. Therefore, it is optimal to set $g_{i}(t)=d_{i}(t)$, and the problem is to maximize (1) subject to (4), (12) and (13). This problem is analogous to the standard consumption-savings problem with a representative agent, and a fixed discount rate.

The effects of an unexpected and temporary increase in $\mathrm{p}(\mathrm{t})$ at $t_{1}$ are well known (Obstfeld and Rogoff (1994), and Razin (1993)). The temporary windfall will be saved in order to be able to smooth government expenditures over the infinite borizon. That is, there is an increase in the growth rate of net public assets during the period $\left[t_{1}, t_{2}\right)$.

In our setup, if the increase in $p(t)$ is permanent, the growth rate of net public assets also increases unambiguously during the period $\left[t_{1}, \infty\right)$. We sbow in Appendix $B$ that if the shock is unanticipated and permanent, the equilibrium is

$$
\begin{aligned}
& d_{i}^{*}(t)=\frac{z(r(p(t)))}{n} A(t) \\
& A^{*}(t)=\left\{\begin{array}{c}
A(0) e^{[r(p)-\delta] \sigma t} \text { for } t<t_{1} \\
A\left(t_{1}\right) e^{\sigma\left[\tau(p)+\theta_{e}-\delta\right)\left[t-t_{1}\right]} \text { for } t \geq t_{1}
\end{array}\right.
\end{aligned}
$$

The value function is bounded if and only $z(r(p+\epsilon))>0$, wbicb we assume to hold. By taking the derivative of (23) with respect to $\epsilon$ we have that

$$
\partial\left(\dot{A}^{-}(t) / A^{*}(t)\right) / \partial \epsilon=\sigma \theta>0 \text { for } t \geq t_{1}
$$

It is interesting to contrast this result witb the divided government case. In that case an improvement in the terms of trade, whether temporary or permanent, leads to a fall in the growth rate of net public assets. With a unitary government, it leads to an increase in the growth rate of net public assets. In neither case is the government benevolent. In botb cases it extracts as much fiscal revenue as possible. Hence we can attribute this difference to the fact that with a unitary government the familiar spending smoothing effect is at work. With a divided government, the existence of the voracity effect does not allow the smoothing effect to operate. That is, if a group were to reduce its appropriation of public assets, it would have no reason to believe that it will gain: the public assets it does not appropiate would be captured by some otber group.

For further reference we will summarise the points made bere in the next proposition 


\section{Proposition 2}

If there exists only one agent that determines the appropriations of each group, or if all powerful groups behave cooperatively, then an unexpected improvement in the terms of trade or in productivity, permanent or transitory, will increase the rate of accumulation of public assets.

\subsection{The Current Account}

The current account can be defined in three equivalent ways: (i) the change in the holdings by domestic citizens of net foreign assets: $C A(t) \equiv \dot{A}(t)+\dot{F}(t)$; (ii) domestic savings minus domestic investment: $C A(t) \equiv S(t)-I(t)$; or (iii) net exports plus net factor payments from abroad: $C A(t) \equiv X(t)-M(t)+f F(t)+\alpha A(t)^{2021}$.

In the previous section we characterized the accumulation of public assets $\dot{A}$. Now we will characterize the private sector accumulation equation $\dot{F}$. Recall that the government sets the tax rate according to (10), and that the representative investor sets $k(t)$ according to (8). It follows that along the equilibrium path the representative investor receives the same rate of return at home and abroad: $f$. Therefore, accumulation equation (7) becomes

$$
\dot{W}(t)=f W(t)-c(t)
$$

Hence the problem of the representative investor is to choose a sequence $\{c(t)\}$ in order to maximize (6) subject to (25). Since the sequence of $d_{i}$ 's is not influenced by the investor, and since the $d_{i}$ 's do not affect the marginal utility of consumption, the choice of $c(t)$ is as in the standard consumption-savings problem. Therefore, using the same methods as in Appendix $B$ it follows that

$$
\begin{aligned}
c^{-}(t) & =z(f) W(t) \\
W^{-}(t) & =W(0) e^{[j-\delta] \sigma t}
\end{aligned}
$$

\footnotetext{
${ }^{2 n}$ In this footnote we show that in our model the three definitions are equivalent. We start with $S-I$. Incone is $p k+\beta \Sigma B+\alpha A+f F$, consumption is $c+\Sigma d_{i}$, and domestic investment is $\Sigma \dot{B}_{i}+\dot{k}$. Thus $\checkmark-I=\left[p k+\Sigma \beta B_{i}+\alpha A+f F-c-\Sigma d_{i}\right]-\left[\Sigma \dot{B}_{i}+\dot{k}\right]$. Since $g_{i}=\dot{B}_{i}-\beta B_{i}+d_{i}$ (by (3)), we have that $S-I=\left[\alpha A+\tau p k-\Sigma g_{i}\right]+[(1-\tau) p k+f F-c-\dot{k}]=\dot{A}+\dot{F}$ (by (2), (7), and $F=W-k$ ). We consider now the third definition. Exports are $p k$, imports are $\Sigma g_{i}+c+\dot{k}$. Following the same steps as before one can show the equivalence of this definition with $\dot{A}+\dot{F}$.

${ }^{21} A(t)$ is composed solely of external assets. We could allow the fiscal authority to also hold domestic assets, in which case $\alpha$ would be interpreted as an index of the average rate of return on commonly-held external and domestic assets. This modification would not substantively alter the central results of the analysis.
} 
$A s$ in the previous section, $z(f)>0$ is necessary for the value function to be bounded. Since $W(t)=F(t)+K(t)$, it follows from (8) and (27) that along the equilibrium path

$$
\dot{F}^{*}(t)=\sigma[\delta-\delta] W^{*}(t)-\theta \dot{A^{*}}(t)
$$

This completes the analysis of the private sector. Substituting (28) in the definition of the current account we obtain the following along the equilibrium path

$$
C A^{*}(t)=[1-\theta] \dot{A}^{*}(t)+\sigma[f-\delta] W^{*}(t)
$$

The current account has two components: the accumulation of net public assets $\dot{A}$ plus the accumulation of net private assets abroad. The latter is the difference between the accumulation of cotal private wealth $\dot{W}$ and domestic private investment $\dot{k}$. Since the domestic government is prone to expropriate, investors just keep at home a portion $\theta A(t)$ of their wealth. Thus $\dot{k}=\theta \dot{A}$.

To analyse the impact effect of an improvement on the terms of trade in the current account we substitute (18) and (23) in (29), take derivatives of (29) with respect to $\epsilon$, and evaluate them at $t=t_{1}$

$$
\begin{aligned}
& \left.\frac{\partial C A^{*}\left(t_{\text {gout. }}^{\text {unitary }}\right)}{\partial \epsilon}\right|_{t=t_{1}}=[1-\theta] \theta A\left(t_{1}\right)>0 \\
& \left.\frac{\partial C A^{*}\left(t_{\text {gout. }}^{\text {divided }}\right)}{\partial \epsilon}\right|_{t=t_{1}}=-\frac{[1-\theta] \theta}{n-1} A\left(t_{1}\right)<0
\end{aligned}
$$

Note that the impact effects of a temporary improvement in the terms of trade are of opposite signs under the unitary and divided government regimes. For the divided government case the intuition is as follows. An increase in $p_{t}$ leads to a fall in the accumulation of public assets. This has two short-run effects. On the one hand it reduces the accumulation of net public assets. This deteriorates the current account one-to-one. On the other hand, there is a reduction in the rate at which the private sector accumulates domestic capital. This improves the current account by a proportion $\theta$. Since $\theta<1$, an increase in the terms of trade deteriorates the current account.

In our model the reaction of the private sector to the shock is an asset reallocation. Private consumption does not react. This is because the government adjusts the tax rate in order to capture all the gains in productivity. Therefore, the change in $p(t)$ does not affect the rate of return on $W(t)$. Hence, the paths of $c(t)$ and $\dot{F}(t)$ are independent of $p(t)$.

Finally, note that since (30) is decreasing in $n$, the deterioration of the current account is greater for $n=2$ than for $n>2$. For further reference we will summarize the results of this subsection in the following proposition 


\section{Proposition 3}

The impact effect of an unexpected improvement in the terms of trade or in productivity, iransitory or permanent, is

- An improvement in the current account if there is just one group with the power to determine fiscal policy, or if all the powerful groups behave cooperatively.

- An detcrioration in the current account if there are multiple groups with the power to determine fiscal policy. Moreover, the greatest deterioration in the current account occurs when $n=2$.

\section{Adjustment to Booms: Case Studies}

We study two episodes of large commodity price movements: the coffee shock of 1975-79 and the oil shock of 1979-82. We consider Indonesia, Mexico and Nigeria, which were big oil exporters, and Cote d'Ivoire, Costa Rica and Cameroon, which were important coffee exporters. In addition, we study the case of Chilean adjustment to copper price fluctuations over 1965-68 and 1984-88. Chile experienced a significant political regime shift in the 1970s, which makes it an interesting laboratory case for the dependence of external adjustment on the structure of the fiscal process. We focus on this small group in order to emphasise the fiscal mechanism highlighted in the model, and because there is consensus in the literature concerning the nature of their fiscal structure ${ }^{22}$.

First, we establish that the disturbances were indeed expected to have a substantial temporary component, such that policies leading to an improvement in the current account were appropiate from a social welfare perspective. Second, we classify fiscal structures according to the degree of central control that exists over public expenditure decisions and show that the bulk of windfalls accrued to the governments of these countries. Third, we consider the savings, investment and current account responses to these shocks and argue that the behaviour of these variables was closely linked to the prevailing fiscal structure and were perverse in those countries in which the fiscal structure was of a common pool type ${ }^{23}$. Conversely, we show that countries which operate under a unitary fiscal process in which adequate controls were imposed on each group with access to the fiscal budget -

\footnotetext{
${ }^{22} \mathrm{Gelb}$ (1988) and Little el al. (1993) survey the adjustment experiences of larger samples of countries.

${ }^{23}$ We emphasise the savings and investment dimensions of edjustment. The effects of a terms of trade boom on the real exchange rate and on the traded sector have been exhaustively analysed in the literature. See Corden and Neary (1982), Neary and van Wijnbergen (1986) and Gavin (1993) .
} 
were better able to avoid such fiscal euphoria and to adjust in the manner prescribed by the representative agent model. Finally, we compare the growth performances of these countries.

The fact that a fiscal process is nominally unitary [e.g. an autocratic leader having executive control over public expenditure] does not mean it is unitary in practice - for instance, an autocrat may depend on the support of provincial bosses to remain in power. Similarly, a federal fiscal structure in itself does not imply the existence of a common pool problem. What matters is whether the potential claimants have the effective power to appropiate resources from the fiscal budget. This is what we try to assess in our study of individual country experiences.

\subsection{The Coffee Shock, 1975-79}

In July 1975, frost destroyed a substantial proportion of Brazil's coffee trees [which take about four years to be replaced]. As a result coffee prices increased 216 percent in 1975-77 before declining in 1978-79. The magnitude of this shock for coffee-exporting nations was large, corresponding to 14.5 percent of GDP in Cameroon in 1976-77, 10 percent in Costa Rica and 25.9 percent in Cote d'Ivoire [see Table 1]. The increase in coffee prices was clearly expected to be a temporary phenomenon and would be reversed when Brazilian production recovered to previous levels. The 1975-79 coffee shock, then, provides a natural experiment of an unanticipated, temporary disturbance for which the representative agent model delivers a clear prediction of current account improvement.

From Table 1 , we see that a large proportion of the coffee windfall directly accrued to the government in the form of higher revenues. While Cameroon succeeded in improving its current account during the period of high coffee prices, Costa Rica and Cote d'Ivoire suffered significant deterioration in their external accounts. A similar pattern appears in the behaviour of government expenditure: Cameroon reduced government spending as a share of GDP during this period, whereas the other two countries experienced an increase in the government's expenditure share. The contrast in country performance is perhaps most striking in terms of the growth rates that were subsequently attained after the coffee boom, with Cameroon growing robustly but Cote d'Ivoire and Costa Rica having little per-capita output growth [see Table 3]. These growth rates may be viewed as a commentary on how productively each country allocated its coffee windfall. We can further illustrate the variation in the efficiency of investment among these countries by a simple numerical example. Take, for example, a 20 percent rate of return on investment as a benchmark figure. Over the 1975-80 period, this benchmark would predict average output growth of 4.4 percent, 5.3 percent and 5.9 percent for Cameroon, Costa Rica and Cote d'Ivoire respectively. Actual 
Table 1: THE COFFÉ SHOCK 1975-79

SIZE OF THE WINDFALL

\begin{tabular}{|c|c|c|c|c|c|c|}
\hline & Cameroon & & Costa Rica & & Cote d'Ivoire & \\
\hline & $(T O T / G D P)_{\iota}$ & $(T O T / X)_{t}$ & $(T O T / G D P)_{t}$ & $(T O T / X)_{t}$ & $(T O T / G D P)_{t}$ & $(T O T / X)_{t}$ \\
\hline 1976 & 6.0 & 50.5 & 6.3 & 23.7 & 12.9 & 44.9 \\
\hline 1977 & 2.7 & 28.0 & 4.7 & 17.7 & 7.3 & 29.3 \\
\hline 1978 & -2.4 & -21.4 & -5.7 & -20.8 & -4.5 & -19.1 \\
\hline 1979 & -1.7 & -14.4 & -.6 & -2.2 & -.6 & -2.7 \\
\hline
\end{tabular}

TOT $=X *\left(\% \Delta P_{X} / \% \Delta P_{M}\right)$ is the size of the terms of trade shock. For an explanation of this formula see Appendix $\mathrm{C}$. $\mathrm{X}$ denotes total exports in constant prices, $P_{X}, P_{M}$ are unit value price indices. Ratios are multiplied by 100 .

ADJUSTMENT TO THE WINDFALL

\begin{tabular}{cccc}
\hline & Cameroon & Costa Rica & Cote d'Ivoire \\
\hline$\Delta C A / G N P$ & .4 & -1.7 & -5.7 \\
$\Delta S / G N P$ & 1.2 & .8 & .5 \\
$\Delta I / G N P$ & 3.5 & 1.8 & 6.1 \\
$\Delta R E V / G D P$ & 2.5 & 3.1 & - \\
$\Delta E X P / G D P$ & -.3 & 3.4 & 3.05 \\
\hline
\end{tabular}

Change in $C A / G N P, S / G N P, I / G N P$ 1976-79 relative to $1970-72$ base. The base period is chosen to abstract from the large oil shock of 1973-74. CA/GNP is ratio of current account to GNP. $S / G N P$ is ratio of national savings to GNP. $I / G N P$ is ratio of domestic investment to GNP. $R E V / G D P$ and $E X P / G D P$ are central government spending and revenue shares. For Cameroon, the base year for $\triangle R E V / G D P$ and $\triangle E X P / G D P$ is 1975 , due to missing data. For Cote d'Ivoire, missing data mean that government consumption proxies for government expenditure and the base is 1971-72. Source: World Tables, Little et al. (1993), IFS. 
growth rates for these countries were 11.6 percent, 4 percent and 4.3 percent respectively. These poor returns on investment in Costa Rica and Cote d'Ivoire relative to the henchmark or Carneroon is in line with our claim concerning the motivations underlying investment decisions in these countries ${ }^{24}$. Next we give some historical background to explain why Cameroon had a unitary fiscal process, while Costa Rica and Cote d'Ivoire did not. We also describe some of the unprofitable projects that were undertaken with the windfall income.

Cameroon moved from pluralist to single-party representation in 1966 and from a federal system to a unitary government in 1972 under President Ahidjo. The shift to a centralised regime was led by Ahidjo and involved the repression of other influential factions in Cameroon, including the jailing in 1962 of four key opposition leaders (Mhida, Okala, Mayi-Matip and Eyidi), the dissolution of the UPC party congress in 1962 and strong pressure on opposition deputies to join Ahidjo's party, the Unjon Camerounaise [see Le Vine (1986) and Connolly (1991)]. Legislators in the dissolved provincial assemblies either retired or were granted sinecure positions by the new regime. This centralisation of power granted substantial executive autonomy to the president. Ahidjo's autonomy facilitated the hanking of the increased revenues, given factional groups' lack of access to the fiscal hudget.

In Costa Rica, the president and Congress failed to recognise the victory of the conservative Otilio Ulate in the 1948 presidential election. As a result, the Social Democratic movement, under Jose Figueres, led an insurrection which resulted in the installation of Ulate as president [see Jacohstein 1987]. In the 1949 constitution, which was written by these two parties, the executive autonomy of the president was severely restricted. The constitution denied the president the right to veto hudgetary laws adopted hy the legislature; provided for the estahlishment of "autonomous institutions" free of presidential influence [two hundred were created hy 1969]; and imposed four year term limits on congressmen. The proliferation of the autonomous institutions, intended as a check on presidential power, had the effect of dividing control over the fiscal process in Costa Rica.

The PLN came to power in 1953 under Figueres and power subsequently alternated hetween the PLN and the conservative party. The import-substitution program and the PLN vision of an interventionist state role in promoting development led to the emergence of a cadre of "politician-entrepreneurs", playing dual roles as important actors in hoth the PLN and Costa Rican industry. These husiness ventures were hacked by the state, either directly or implicitly through soft credit policies. The most important vehicle for the activities of the "politician-entrepreneurs" was CODESA, the state holding company, which was established in 1972. CODESA was state-owned but constituted as a private corporation

\footnotetext{
${ }^{24}$ See Devarajan and de Melo (1987) for a comparison of Cameroon and Cote d'Ivoire.
} 
and, remarkahly, was granted direct access to Central Bank financing. During the coffee boom, the subsidiaries of CODESA invested aggressively buying out struggling private firms and establisthing publicly-owned enterprises in activities such as fertilizer, cement, aluminum smelting, sugar, cotton and aquaculture, obtaining financing from the Central Bank and from external borrowing. This expansion in activities was highly unprofitable, with losses never less than 25 percent of sales in each year[see Gonzalez-Vega and Cespedes 1993].

A good illustration of the autonomy of these actors is the CATSA sugar mill scandal [see Achio and Escalante 1985]. This project was initiated in 1975 [contemporaneous with the boom in coffee revenues] and was financed by CODESA. Construction suffered from time overruns, and even when production began, productivity was very low [two-thirds that of privately-owned mills]. CATSA faced bankruptcy in 1982 with a debt of 400 million escudos. The National Bank of Costa Rica and CODESA bailed it out. The accumulation of this debt could be traced back to overruns on construction costs and a land-buying spree in 1977 at prices $30-40$ percent above market values. This overspending was attributed to the political motivation underlying the entire project. It is noteworthy that these budget overruns were incurred wisen government coffee revenues were at their peak during 1975-77. The sugar industry in Costa Rica was dominated by entrepreneurs with close links to leading PLN officials, inclisdiug Rodrigo Arias [the brother of the planning minister and future president Oscar Arias], Manuel Dobles, Alvaro Jenkins [the minister of transportation], Alonso Lara and Mario Hoffmaister. The latter three 'sugar-entrepreneurs' were on the board of the CATSA sugar mill.

Since independence, formal power in Cote d'Ivoire has been concentrated in the hands of President Houphouet-Boigny ${ }^{25}$. From the 1950s until 1990, there was a single party (the PDCI). Initially it was dominated by the president and his associates, the anciens. This changed during the 1970s. First, limited opportunities for influence generated discontent among new members of local elites, the jeunes. The discontent became so severe that in 1975 the president had to expand the number of ministries and allow jeunes in, leaving only six anciens. Additionally, party barons with significant political machines had emerged and appeared to be engaged in a succession race ${ }^{26}$.

The timing of the coffee windfall coincided with the tensions among regional elites and large projects were inaugurated in regional centers. These totaled 100 billion CFA. The best known was the massive SODESUCRE program to create irrigated sugar plantations destined

\footnotetext{
${ }^{35}$ His tenure ended only with his death in January 1994.

${ }^{26}$ The power of the anciens was reduced in 1980 by the calling of multicandidate assernbly elections and in 1990 by the legalisation of opposition parties.
} 
to produce sugar at costs above projected world prices. Overbilling was so acute that by 1982 it had wiped ont the entire value added of the company (10 billion CFA). Party barons also increased fiscal spending in their regions in order to strengthen their position in the succession race. The most powerful were the party chief Philippe Yace (Jacqueville), army chief Koudio M'Bahia Ble (M'Bahiakro) and the Coulibaly family (Korhogo) ${ }^{27}$. In addition, during the 1970s, the president bad to deal with a feud within the Coulibaly family and attempt to reduce the wealth gap between the dominant south and the central and northern ethnic groups in order to maintain the stability which was perceived as the cornerstone of his regime.

The 1975-79 coffee shock, in summary, provides a natural experiment in country adjustment to a temporary positive terms of trade shock. Cote d'Ivoire and Costa Rica adjusted incautiously to the windfall, whereas Cameroon succeeded in banking much of the increased revenues, allowing for the maintenance of higher consumption after the boom was over. We have argued that the differences in fiscal structures described above help explain this variation in adjustment behaviour.

\subsection{The 1979-82 Oil Shock}

The origins of the 1979-80 oil price increase lay in the overthrow of the Shah in 1978, which reduced oil exports from Iran and generated uncertainty about future oil supplies These circumstances suggested that the oil price increase had a substantial temporary component. Expert opinion at the time was that oil prices would significantly decline by the mid-1980s, once oil exports from Iran resumed. The contemporary trade journals cited the large stockpiles in oil-importing countries and the prospect of global recession as reasons why the price increase would not be sustained [see Petroleum Economist, Oil and Gas Journal, Adelman (1980)]. In 1978, Data Resources Inc. projected that the real oil price needed to rise by 25 percent by 1990. Given that the actual supply reduction from Iran was low [4\% of world production] and the existence of large stocks, this suggested that much of the 1979-80 oil price increase would be unwound over time. Salomon Bros. argued that the OPEC price increase "in reality should be viewed as a 2 -year increase ${ }^{n}$ [Oil and Gas Journal, 1/29/79]. The Economist took the position "It is possible OPEC will seize the opportunity of a smallscale shortage to send prices temporarily soaring... . In time, the unstable oil markets will return to their prevailing structural shortage ${ }^{n}(2 / 17 / 79)$. The perception that the shock was temporary is also reflected in the stock price performance of US-based nondiversified oil

\footnotetext{
${ }^{27}$ See Widner (1994), Zartman and Delgado (1984).
} 
companies ${ }^{28}$. Over the 1977-1980 period, while the oil price increased 152 percent, average share prices for these companies rose by only 54.4 percent [the S\&P 500 rose by 42.8 percent]. Furthermore, it is striking that, even though the oil price climbed an additional 47 percent in 1981 , oil shares fell 19.5 percent [the fall in the S\&P 500 was only 9.7 percent] ${ }^{29}$. This pattern is consistent with permanency of the shock only if an implausibly large demand elasticity for oil and/or extremely strong countercyclical profit margins in refining are assumed.

From Table 2 , it is clear that national governments captured a large proportion of the oil price windfall. We see that Indonesia responded to the oil windfall with an improvement in its current account, while Mexico and Nigeria responded with a deterioration of the current account. Again, we see from Table 2 that the difference in current account behaviour is mirrored by the paths of government spending in these countries. The contrast between the cautious adjustment response in Indonesia and the spendthrift policies in Mexico and Nigeria is striking ${ }^{30}$. The subsequent growth performances of these countries during the $1980 \mathrm{~s}$ also suggest that Indonesia allocated its windfall more productively than either Mexico or Nigeria [see Table 3]. Taking again the 20 percent investment rate of return benchmark figure, predicted average total output growth for Indonesia, Mexico and Nigeria over the 1979-84 period would have been 5.7 percent, 5 percent and 3.2 percent respectively. Actual growth rates were 6.1 percent, 4.2 percent and -1.6 percent respectively. This suggests the return on investment projects undertaken in Mexico and Nigeria was low.

Next we give some historical background to explain why Indonesia had a unitary fiscal process, while Mexico and Nigeria did not. After the political turmoil of 1965-66, General Suharto replaced Soekarno as the president of Indonesia. The massacre of Communist Party members by the army and the economic disruptions of this period - hyperinflation and a sharp decline in output - had created a strong popular desire for stability and order. This granted Suharto and his military backers considerable autonomy. Suharto strengthened his power via a network of army officers, civil servants, and state corporations [the Golkar]. In order to ensure economic stability, a group of university professors, the Berkeley Mafia, was allowed to design an orthodox macroeconomic program for Indonesia. These economists have remained in office until the present, and their program has remained highly influential in Indonesian policymaking.

The fiscal conservatism of the Suharto administration was further enhanced by the experience of the Pertamina crisis of 1974-75, in which the head of the state oil company, General

\footnotetext{
${ }^{26}$ These companies gained from the increase in the oil price but were not exposed to expropriation risk from the spread of political instability from Iran to other Gulf nations

${ }^{29}$ See Appendix D.

${ }^{30}$ See Pinto (1987) for a comparison of lndonesia and Nigeria.
} 
Table 2: OIL SHock 1979-82

SIZE OF THE WINDFALL

\begin{tabular}{ccccccc}
\hline & Indonesia & \multicolumn{5}{c}{ Mexico } \\
\hline & $(\text { TOT } / G D P)_{t}$ & $(\text { TOT } / X)_{t}$ & $(\text { TOT } / G D P)_{t}$ & $(\text { TOT } / X)_{t}$ & $(\text { TOT } / G D P)_{\mathrm{t}}$ & $(\text { TOT } / X)_{\mathrm{t}}$ \\
1979 & $9 . \bar{t}$ & 27.6 & .4 & 13.1 & 13.4 & 26.5 \\
1980 & 8.6 & 24.8 & 2.1 & 17.8 & 20.1 & 45.4 \\
1981 & 1.5 & 5.7 & .8 & 6.8 & 3.0 & 9.6 \\
1982 & -.8 & -3.4 & -.4 & -2.8 & -3.0 & -7.4 \\
\hline
\end{tabular}

AdJUSTMENT TO THE WindFALL

\begin{tabular}{cccc}
\hline & Indonesia & Mexico & Nigeria \\
\hline$\Delta C A / G N P$ & 1.82 & -2.35 & -1.25 \\
$\Delta S / G N P$ & 4.8 & 8.15 & -4.7 \\
$\Delta I / G N P$ & 3.7 & 3.8 & -5.9 \\
$\triangle R E V / G D P$ & 3.85 & 3.1 & - \\
$\triangle E X P / G D P$ & .85 & 5.8 & 1.55 \\
\hline
\end{tabular}

See note to Table 1. $\triangle C A / G N P, \triangle S / G N P, \triangle I / G N P$ are average changes $1979-82$ relative to 1975-77. Base period chosen for its lack of terms of trade volatility. Nigeria: revenue data missing and $\triangle E X P / G D P$ is change in 1979-81 relative to 1975-77. Source: IFS, World Tables, Little et al. (1993). 
Sutowo, had used oil revenues to fund a massive diversification programme and ill-advised speculation in the international oil tanker industry. Following this scandal the Berkeley mafia was able to implement tighter controls on parastatal spending and restrict access of SOEs to international credit markets [see Bresnan 1993].

The Mexican political system is dominated by the president, who has overwhelming formal authority but may not seek reelection, and the PRI, which has won all the presidential elections since the 1930s. Contrary to popular belief, the apparent autonomy of the president is limited by "strong groups that fight against each other to obtain the Presidential favors... with the consequence that the President always tries to find, timidly and vacillating, a half way that will not hurt anybody"31.

After the revolution of 1910 , the country fell into a state of anarchy, with different military caudillos ruling each region of the country. In 1929, after many attempts, President Calles was able to organise the local military caudillos into one political party and transform them into "businessmen". In exchange for privileges such as monopoly rights in different industries and subsidized credit, the bargain was that this elite would be loyal to the PRI and ensure electoral victories in their localities [Cordova (1972)]. The economy evolved into a highly protected and regulated system, where the president could exercise ample power as long as he did not violate the rights of the "Revolutionary Family". By the 1970s, one could distinguish two strong groups: the private import-competing elite, and the elite associated with the SOEs ${ }^{32}$.

In the early 1970s, Mexico was a net oil importer but vast oil reserves were announced in 1977. Mexican oil production increased from an annual 305 million barrels in 1976 to 1 billion barrels in $1982^{33}$. The oil boom had a positive impact on fiscal revenues, which increased by 3.1 percent of GDP in 1979-82 [see Table 2]. The mechanisms by which the windfall was appropriated by fiscal claimants were: increased public investment in SOEs, unconditional government guarantees of private foreign loans, bailouts of bankrupt firms and outright transfers. Some examples will suffice to show that these projects; far from being the realization of profitable investment opportunities, were vehicles for redistributing fiscal resources. First, an agreement with the oil workers' union stipulated that 40 per cent of all contracts granted by PEMEX, the state oil monopoly, were to be awarded to the union [the union was of course free to subcontract]. The second example has to do with SOEs, which

\footnotetext{
${ }^{31}$ The quote is from Daniel Cosio Villegas (1976), p.8, a leading Mexican historian.

${ }^{32}$ It was not until the mid-1980s, when the terms of trade collapsed 50 per cent, that the elites clashed and weakened each other. This gave the President autonomy to act and implement radical trade liberalization, deregulation and privatization programs [see Tornell (forthcoming)].

${ }^{33}$ Twentieth Century Petroleum Statistics (1993).
} 
Table 3: Per Capita GDP Growth Rates

\begin{tabular}{cccccccc}
\hline & Cameroon & Costa Rica & Cote d'Ivoire & & Indonesia & Mexico & Nigeria \\
\hline $65-75$ & 1.48 & 1.39 & 1.53 & $69-79$ & 2.45 & 1.41 & 1.96 \\
$75-78$ & 1.99 & 2.03 & .9 & $79-82$ & 3.27 & 1.05 & -2.26 \\
$78-85$ & 2.19 & -.57 & -.9 & $82-88$ & 1.71 & -1.07 & -2.15 \\
\hline
\end{tabular}

Source: Summers and Heston (1991).

increased in number from 504 in 1975 to 1155 in 1982 . The expansion of the parastatal sector included the bailing out of struggling private firms. The government ended up owning a loss-making cabaret, a bicycle plant and a cookie producer, amongst others. Parastatals also expanded production capacity. The most prominent example is the industrial complex developed in the town of Lazaro Cardenas, which consisted of a steel plant, a fertilizer plant, a capital equipment plant and a big diameter pipe producer ${ }^{34}$. Although the steel plant was designed to produce two million tons of plate (final good), it did not produce even one million tons of slab (intermediate good). Moreover, the steel plant was of the direct reduction type, which uses, instead of coal, gas and electricity which are scarce in Mexico. All these plants had operating losses. The third example concerns a major private industrial group: Alfa. It embarked on an aggressive diversification programme, financed by external borrowing. A number of these investments turned out to be unprofitable and in 1981, months before the debt crisis, it received from the government $\$ 500$ million to repay its debts.

The source of divided fiscal control in Nigeria has been strong regional and ethnic tensions. These tensions erupted into civil war in 1966 when the eastern region attempted to secede, and form the republic of Biafra. A military government took power and attempted to reduce inter-regional tensions by expanding the number of states and increasing the nominal authority of local governments. In 1979 a democratic regime, led by Shehui Shagari, was installed. The federal government proposed a Revenue Allocation Act which would have

\footnotetext{
${ }^{31}$ Murphy (1983) estimates the steel plant was the sixth largest construction project in the developing world [excluding the Gulf states] at the time, at a cost of $\$ 8$ billion.
} 
shared revenues according to objective criteria in order to eliminate the fiscal struggle among regions. This legislation, however, was nullified by the courts. The result was that states relied on informal bargaining with the federal government in obtaining ex-post financing for spending plans already carried out [see Ukpong 1986]. National control on spending was further weakened in 1980 when states were granted the right to borrow directly from abroad without requiring approval from the federal government.

The most notorious examples of the squandering of the oil windfall were the construction of a new capital city in Abuja, which began in 1981, and the development of the steel industry ${ }^{35}$. Rivalry among regions led to duplication of investment projects, with steel mills being built in both Ajaokuta and Aladja regions. Each plant has capacity of one million tons, while total domestic demand for steel in Nigeria is around half million tons. The estimated cost of each project was $\$ 1$ billion. However, the costs turned out to be $\$ 2$ and $\$ 4$ billion respectively. What is worse is that these plants have never operated at more than 25 percent capacity. The managing director of the International Bank of West Africa estimated the proportion of diverted funds in public investment projects at 75 percent. One leading civil servant, Phillip Asiodu, remarked, in relation to the fiscal anarchy of this period, "it was so much easier to sign up road and harbour projects and other infrastructural construction projects and run down our reserves in the process" [quoted in Bangura 1987].

\subsection{Copper and Chile}

Chile is an interesting case study for two reasons. First, its dependence on copper exports for foreign currency left it highly vulnerable to externally-driven fluctuations in the world price of copper. Second, after the military coup in 1973, Chile experienced a dramatic shift in its fiscal process from divided control to a unitary regime.

Table 4 shows how during the 1965-69 period the current account was strongly negatively correlated with the terms of trade. In contrast, during the 1984-1988 period this correlation became positive.

Since the nineteenth century Chile had been a democracy, with a strong parliament dominated by a rural elite. As export earnings collapsed in the 1930s, there was a shift to import substitution and government intervention [see Alexander 1978]. In this sheltered economy, new fiscal claimants emerged: the import-substituting private elite and urban labor unions. By the 1950s, each had acquired strong influence on policymaking. As an example, Velasco [1993] details that private business interests had one-third representation on the

\footnotetext{
${ }^{35}$ What follows draws on Bangura (1987) and Montenegro (1993).
} 
Table 4: Chilean AduUstment

\begin{tabular}{|c|c|c|c|c|c|c|c|}
\hline & $(T O T / G D P)_{t}$ & $(T O T / X)_{\mathrm{t}}$ & $\triangle C A / G N P$ & $\Delta S / G N P$ & $\Delta J / G N P$ & $\triangle R E V / G D P$ & $\Delta E X P /$ \\
\hline 1965 & 1.5 & 12.3 & 1.8 & 2.2 & .7 & 2.3 & 1.5 \\
\hline 1966 & 3.1 & 22.5 & -.8 & -.4 & -.1 & 2.1 & 1.3 \\
\hline 1967 & -.7 & -5.2 & .5 & -2.5 & -2.6 & 1.1 &.$- \ddot{3}$ \\
\hline 1968 & .9 & 6.7 & -1.2 & .2 & .7 & .7 & 1 \\
\hline 1985 & -.5 & -1.7 & 2.3 & 2.9 & .3 & .2 & -1.5 \\
\hline 1986 & -2.5 & -9 & 1.9 & 2 & 1.1 & -.7 & -1.5 \\
\hline 1987 & 2.2 & 7.7 & 3.3 & 5.8 & 2.9 & .5 & -.9 \\
\hline 1988 & 4.4 & 15.9 & 3.9 & 3.8 & 0 & -.4 & .5 \\
\hline
\end{tabular}

Source: International Monetary Fund IFS. ECLA. Ffrench-Davis (1973). International Monetary Funds IFS. World Tables.

Table 5: Chilean Per Capita Growth

\begin{tabular}{ccccccc}
\hline $60-65$ & $65-70$ & $70-73$ & $73-83$ & $83-86$ & $86-88$ & $88-91$ \\
\hline 1.1 & 1 & .04 & -.4 & .8 & 1.8 & 4.2 \\
\hline
\end{tabular}

Source: Summers and Heston (1991). 
boards of major policymaking agencies and fiscal allocations could not be decided without the approval of leading industrialists. The lour most powerful business organizations had voting inembership in such major policy institutions as the state financial agency CORFO and the Central Bank. CORFO could in effect issue money, with the result that industrialists were able to channel public resources, in the forms of subsidies and cheap credit, to their own businesses. Militant urban labour unions, led by the Socialist and Communist Parties, captured some of these rents [see Ffrench-Davis (1973)].

In 1964 the Christian Democratic Party (the ADC), formed in the 1950s, obtained the presidency under Eduardo Frei. The ADC, however, did not control the Senate and faced strong opposition to its ambitious land redistribution program. In order to establish an independent power base, the ADC formed still more claimants on the state: rural unions and urban-poor organizations. The degree of division was reflected in an increase in the number of strikes from 676 in 1966 to 1623 in 1970 [Mendez (1980)].

The regime shift started in 1970, when the socialists under Allende obtained tbe presidency. They implemented a radical and violent expropriation program, which dealt a blow to the rural and business elites. The response was a military coup in 1973 headed by Pinochet. To the surprise of many, Pinochet liberalized trade in 1975, destroying most of tbe import substituting sector. This was the final blow to the political power of the business elite. Industrialists, however, did not oppose trade liberalization because it was the means to emasculate the labour unions [indeed, the unionization rate declined from nearly 40 percent in 1973 to 12 percent in 1989]. Business interest turned to the export of forestry and agricultural products and the services sector. As established elites weakened one another, then, the Pinochet regime acquired autonomy to act, converting Chile to a unitary fiscal structure [Velasco (1993)].

\section{Conclusions}

In several countries that have enjoyed sizable temporary terms of trade improvernents, the current account has not improved in the face of the temporary windfall. Also, windfalls appear to be as much a curse as a blessing, in that they do not lead to an increase in the growth rate of these countries. This appears to be related to increased spending on inefficient capital projects.

Tbe point we make in this paper is that the structure of the fiscal process is critical in determining outcomes. In countries in which there exist strong control over the national budgetary process, pressures to increase spending in the wake of extra resources can be suc- 
cessfully resisted, and an improvement in the current account takes place - as predicted by representative-agent models of the current account. Conversely, if there is divided control over the fiscal process, via excessive autonomy on the part of subnational levels of government, the parastatal sector or spending ministries, then the voracity effect described in this paper is allowed to operate and a perverse outcome occurs.

We model the interaction among the clamants on the state as a differential game, and establish theoretical support for the "horror stories" of wasteful investment responses and negative movements in the current account in response to terms of trade improvements. When a positive shock occurs, the common national budget constraint is relaxed and it is privately optimal for each powerful group to appropiate extra public assets, even if this implies storing them inefficiently (e.g. in unproductive investment projects). We show that in equilibrium aggregate appropriation grows more than the windfall itself, regardless of the expected duration of the shock. This results in a deterioration of the current account. We also show that in equilibrium all the windfall is dissipated, with the country experiencing no increase in its GDP growth and with no welfare gain, despite the favourable relative price movement.

An implication of the model is that when fiscal control is divided, countries that enjoy windfalls fail to attain higher growth rates. This is because the windfall induces an increase in redistributive activity. Although there is an increase in investment, it is typically directed towards inefficient projects. As a result the aggregate growth rate does not increase. We believe that this investment-composition channel can help reduce the significance of the significance of African and Latin American dummies in cross-country growth regressions.

In future work we plan to test the predictions of the model for the current account responses and growth rates in a large panel of countries. Such a project involves constructing an index that directly measures the degree of division of control over the fiscal process. Typologies such as democracy versus autocracy do not bave predictive power, as is clear from our case studies.

\section{Appendix}

\section{A The Divided Government Case}

We will find $n$ strategies, one for each group: $\left(\left\{d_{i}(t)\right\},\left\{g_{i}(t)\right\}\right)$, with the property that starting at each instant, strategy $i$ maximizes the payoff of group $i$, taking as given the strategies of the other n-1 groups, and subject to (3), (4), (12) and (14). A pair $\left(\left\{d_{i}(t)\right\},\left\{g_{i}(t)\right\}\right)$ is 
optimal for group $i$ only if it satisfies the first order conditions associated with the following present value llamiltonian

$$
\begin{aligned}
H_{i}\left(A, B_{i}, g_{i}, d_{i}\right)= & \sigma /[\sigma-1] d_{i}(t)^{[\sigma-1] / \sigma}+\psi_{i}(t)[r(p(t)) A(t)- \\
& \left.\Sigma_{j \neq i} x_{j}(p(t)) A(t)-g_{i}(t)\right]+\phi_{i}(t)\left[\beta B_{i}(t)+g_{i}(t)-d_{i}(t)\right]
\end{aligned}
$$

We did not include the inequality constraints (4) and (14). It turns out that they are not binding in the interior equilibrium. The first order conditions are

$$
\begin{aligned}
& d_{i}^{*}(t)=\phi_{i}(t)^{-\sigma} \\
& \psi_{i}(t)=\phi_{i}(t) \\
& \dot{\phi}_{i}(t) / \phi_{i}(t)=\delta-\beta \\
& \dot{\psi}_{i}(t) / \psi_{i}(t)=\delta-r(p(t))+\Sigma_{j \neq i} x_{j}(p(t)) \\
& \phi_{i}\left(t_{2}\right) e^{-\delta t_{2}}=\partial J\left(B_{i}^{*}\left(t_{2}\right)+A^{*}\left(t_{2}\right)\right) / \partial\left(B_{i}(t)+A(t)\right) \\
& \lim _{t \rightarrow \infty} A(t) \psi_{i}(t) e^{-\delta t}=0, \quad \lim _{t \rightarrow \infty} B_{i}(t) \phi_{i}(t) e^{-\delta t}=0
\end{aligned}
$$

where $\mathrm{J}$ is the maximized value of (1). To find an equilibrium candidate, we need to find $\mathrm{a}$ pairs $\left(\left\{d_{i}(t)\right\},\left\{g_{i}(t)\right\}\right)$ that simultaneously satisfy $n$ sets of equations (A.2)-(A.7), one for each group $i$. First we determine the form that the unknown functions $x_{i}^{*}(p(t))$ have to take. From (A.3)-(A.5) it follows that along an interior equilibrium it is necessary that for each $i$, $r(p(t))-\beta=\Sigma_{j \neq i} x_{j}(p(t))$. This condition holds for every $i$ if and only if for each $t$ all $x$ 's are identical. Therefore, the unique value that $x_{j}(p(t))$ can take in an interior equilibrium is $x_{j}^{*}(p(t))=[r(p(t))-\beta] /[n-1]$. Substituting this expression for $x_{j}$ in accumulation equation (12) we obtain the equilibrium path of $A(t)$ in (18). Now we derive the equilibrium expenditure path. Conditions (A.2) and (A.4) imply that

$$
d_{i}(t)=d_{i}(s) e^{\sigma[\beta-\delta][t-s]}, \forall t, s
$$

Substituting (A.8) and (16) in accumulation equation (3), and solving the differential equation we get that for all $t$ and $s$

$$
B_{i}(t)=e^{\beta[t-s]}\left\{B_{i}(s)+A(s)\left[1-e^{-x^{*}(p(t))[(-s)}\right]-\left[1-e^{-z(\beta)(t-s)}\right] d_{i}(s) / z(\beta)\right\}
$$

To have a complete characterization of the equilibrium path we need to determine the values of $d_{i}^{*}\left(t_{0}\right), d_{i}^{*}\left(t_{1}\right)$ and $d_{i}^{*}\left(t_{2}\right)$. We start with $d_{i}^{*}\left(t_{2}\right)$. Substituting (A.2), (A.8) and (A.9) in the second transversality condition (A.7) we get

$$
\lim _{t \rightarrow \infty} d_{i}\left(t_{2}\right)^{-\frac{1}{\sigma}}\left\{B_{i}\left(t_{2}\right)+A\left(t_{2}\right)\left[1-e^{-x^{*}(p)\left[\left(-t_{2}\right]\right.}\right]-\left[1-e^{-z(\beta)\left(t-t_{2}\right)}\right] \frac{d_{i}\left(t_{2}\right)}{z(\beta)}\right\}=0
$$


It follows from (5), (9) and (13) that $r(p(t))>\beta$. Thus $x^{*}(p(t))>0$. Also, we have that $z(\beta)>0$ by (15). Therefore, the transversality condition is satisfied if and only if

$$
d_{i}^{*}\left(t_{2}\right)=z(\beta)\left[A\left(t_{2}\right)+B_{i}\left(t_{2}\right)\right]
$$

Substituting (A.11) in (A.9) we obtain the equilibrium path of group i's private assets for $t \geq t_{2}$

$$
B_{i}^{*}(t)=B_{i}\left(t_{2}\right) e^{\sigma[\beta-\delta]\left[t-t_{2} \mid\right.}+A\left(t_{2}\right)\left[e^{\sigma[\beta-\delta]\left[t-t_{2}\right]}-\exp \left(\frac{n \beta-r(p)}{n-1}\left[t-t_{2}\right]\right)\right]
$$

Substituting (A.11) and (18) in (1) it follows that the value of the continuation garne at $t=t_{2}$ is

$$
J_{i}\left(A\left(t_{2}\right)+B_{i}\left(t_{2}\right)\right)=\frac{\sigma}{\sigma-1}\left[A\left(t_{2}\right)+B_{i}\left(t_{2}\right)\right]^{\frac{\sigma-1}{\sigma}} z(\beta)^{-\frac{1}{\sigma}} e^{-\delta t_{2}}
$$

This integral is bounded only if $z(r(p+\epsilon))>0$.

Next we determine $d_{i}^{*}\left(t_{1}\right)$. Taking the derivative of (A.13) with respect to $A+B_{i}$, and substituting it in the transversality condition (A.6), we get that $\phi_{i}\left(t_{2}^{-}\right)^{-\sigma}=z(\beta)\left[A\left(t_{2}\right)+\right.$ $B_{i}\left(t_{2}\right)$. Substituting this in (A.2) we get

$$
d_{i}^{-}\left(t_{2}^{-}\right)=z(\beta)\left[A\left(t_{2}\right)+B_{i}\left(t_{2}\right)\right]=d^{-}\left(t_{1}\right) e^{((\sigma(\beta-\delta) \Delta)} \Delta \equiv t_{2}-t_{1}
$$

The second equality follows from (A.8). Substituting (18) and (A.9) in (A.14) we get

$$
\frac{d_{i}^{*}\left(t_{1}\right)}{z(\beta)} e^{\sigma(\beta-\delta) \Delta}=A\left(t_{1}\right) e^{x^{*}\left(t_{1}\right) \Delta}+e^{\beta \Delta}\left\{B_{i}\left(t_{1}\right)+A\left(t_{1}\right)\left[1-e^{-x^{*}\left(t_{1}\right) \Delta}\right]-\left[1-e^{-z(\beta) \Delta}\right] \frac{d_{i}^{*}\left(t_{1}\right.}{z(\beta)}\right\}
$$

Substituting the equilibrium level of $x^{*}$ given in (16) and $z(\beta)=\beta[1-\sigma]+\delta \sigma$ in (A.15) we obtain $d_{i}^{*}\left(t_{1}\right)=z(\beta)\left[A\left(t_{1}\right)+B_{i}\left(t_{1}\right)\right]$. Thus, it follows from (A.8) that

$$
d_{i}^{*}(t)=z(\beta)\left[A\left(t_{1}\right)+B_{i}\left(t_{1}\right)\right] e^{\sigma[\beta-\delta]\left[t-t_{1}\right]}, t \in\left[t_{1}, t_{2}\right)
$$

Substituting (A.16) in (A.9) and setting $s=t_{1}$, it follows that for $t \in\left[t_{1}, t_{2}\right)$

$$
B_{i}^{*}(t)=B_{i}\left(t_{1}\right) e^{\sigma[\beta-\delta]\left[t-t_{1}\right]}+A\left(t_{1}\right)\left[e^{\sigma[\beta-\delta]\left[t-t_{1}\right]}-\exp \left(\frac{n \beta-r(p)-\theta \epsilon}{n-1}\left[t-t_{1}\right]\right)\right](A
$$

Next we consider the time interval $\left[0, t_{1}\right)$. Since the shock that occurs at $t_{1}$ is unexpected at $t<t_{1}, d_{i}^{-}(0)$ and $B_{i}(t)$ are given by (A.11) and (A.12), replacing $t_{2}$ by 0 .

This completes the characterization of the interior equilibrium. To see that the candidate pair $\left\{g_{i}^{*}(t), d_{i}^{*}(t)\right\}$ given by (16) and (17) is admissible, note first that it generates a unique 
state trajectory $\left\{A^{*}(t), B_{i}^{*}(t)\right\}$ given by (18) and (19). Second, that it satisfies the necessary conditions (A.2)- (A.7). Third, that constraints (4) and (14) are satisfied: $g_{i}^{*}(t)<\bar{x} A(t)$ follows from (16) and (14), and (4) is not binding along the equilibrium path because $\dot{B}_{i}^{*}>0$ by (15).

Lastly, we show that the admissible pairs $\left\{g_{i}^{*}(t), d_{i}^{*}(t), i=1, \ldots, n\right\}$ constitute an equilibrium. That is, that no group would attain a higher payoff (as measured by (1)) by deviating unilaterally. Theorem 2.3 of Mehlman (1988) states that this holds if and only if the Hamiltonian (A.l) evaluated at the optimum $H_{i}\left(A, B_{i}, g_{i}^{*}\left(A, B_{i}\right), d_{i}^{*}\left(A, B_{i}\right)\right)$ is concave in $\left(A, B_{i}\right)$. Substituting (16) and (17) in (A.1) and taking derivatives we find that

$$
H_{A A}^{*}=H_{A B_{i}}^{*}=H_{B_{i} B_{i}}^{*}=-\left[A+B_{i}\right]^{\frac{-\sigma-1}{\sigma}} z(\beta)^{\frac{-1}{\sigma}}<0
$$

This implies that the associated Hessian is negative semidefinite: the Hamiltonian is concave. Since $x^{*}(p(t))$ in (16) is the unique solution to the system of $n$ equations derived from (A.3). (A.5) (one for each $i$ ), we conclude that (16)-(17) is the unique interior Markov perfect equilibrium.

\section{B The Unitary Government Case}

We solve here for the permanent shock case. The present value Hamiltonian of this problem is

$$
H=(\sigma /[\sigma-1]) d(t)^{\sigma /[\sigma-1]}+\lambda(t)[r(p+\epsilon)-d(t)]
$$

We did not include the inequality constraint (4). It turns out that it is not binding along equilibrium path. The first order conditions are

$$
\begin{aligned}
& d^{*}(t)=\lambda^{*}(t)^{-\sigma} \\
& \lambda^{*}(t) / \lambda^{*}(t)=\delta-r(p+\epsilon) \\
& \lim _{t \rightarrow \infty} A(t) \lambda(t) e^{-\delta t}=0
\end{aligned}
$$

Using the same method as in appendix $A$, it follows that $d_{i}^{*}(t)=z(r(p)) A(t) / n=[r(p+$ $\epsilon)[1-\sigma]+\delta \sigma] A(t) / n$. To see that condition (B.4) is satisfied we substitute (22), (23) and $(\mathrm{B} .2)$ in (B.4)

$$
\lim _{t \rightarrow \infty} A(0) e^{\sigma[r(p+c)-\delta] t}\left[\lambda(0) e^{[\delta-r(p+c)] t} e^{-\delta t}=\lim _{t \rightarrow \infty} A(0) \lambda(0) e^{-z(r(p+c)) t}=0\right.
$$

The second equality follows from $z(r(p+\epsilon))>0$, which is a necessary condition for the value function to be bounded. 
Table 6: The Current Account and Terms of Trade, 1971-1985

\begin{tabular}{ccccccccc}
\hline & $\beta_{0}$ & $\beta_{1}$ & $\beta_{2}$ & $\beta_{3}$ & $\beta_{4}$ & $\sum_{j=0}^{4} \beta_{j}$ & $\bar{R}^{2}$ & NOBS \\
\hline & $.38^{* *}$ & $-.34^{* *}$ & $-.13^{* *}$ & $-.13^{* *}$ & $-.08^{* *}$ & $-.3^{*}$ & .28 & 218 \\
S.E. & .08 & .07 & .03 & .03 & .03 & .16 & & \\
\hline
\end{tabular}

Country and time effects are insignificant and not reported. Standard errors are Whitecorrected. Jarque-Bera normality test $=8.22$ ( $p$-value $=.016$ ). ${ }^{* *}$ denotes significance at $1 \%$ level, " significance at $5 \%$ level. Data source: World Bank, World Tables 1993.

\section{Panel Data Evidence}

Our objective is to identify the relationship between movements in the terms of trade and the current account, allowing for delays in adjustment responses to shocks. Typically, the contemporaneous correlation of the current account and the terms of trade is positive. This captures the fact that public spending cannot be adjusted immediately after the unexpected shock occurs. However, once adjustment in spending behaviour occurs, the initial improvement is more than offset by increased dissaving in subsequent periods. We ran a regression of the form

$$
\Delta(C A / G N P)_{i t}=\alpha_{i}+\rho_{t}+\sum_{j=0}^{4} \beta_{j}(T O T / G N P)_{i t-j}+\mu_{i t}
$$

where $\alpha_{i}$ is a country-specific constant, $\rho_{t}$ is a time dummy and

TOT $T_{i t}=X_{i t} *\left(\left(P_{X i t}-P_{X i t-1}\right) / P_{X i t-1}\right) /\left(\left(P_{M i t}-P_{M i t-1}\right)\right) /\left(P_{M i t-1}\right)$ where $X_{i t}$ is volume of exports, $P_{X i t}$ and $P_{M i t}$ are unit value indices. By weighting price movements by export share only, the TOT is a measure of the impact of the terms of trade shock which is independent of trade imbalance distortions. The results are given in Table 6 . The estimate of $\sum_{j=0}^{4} \beta_{j}$ is significantly negative at the 5 percent level: a terms of trade improvement leads to an average current account decline over a five year period. The countries selected are the union of countries studied in Gelb (1988) and Little et al. (1993). The list is Algeria, Argentina, Brazil, Cameroon, Chile, Colombia, Costa Rica, Cote d'Ivoire, Ecuador, India, Indonesia, Kenya, Korea, Mexico, Morocco, Nigeria, Pakistan, Sri Lanka, Thailand, Trinidad and Tobago, Turkey and Venezuela. 
Table 7: Oil Share Performance, 1977-81

\begin{tabular}{cccc}
\hline \hline Year & Oil Price & S\&P 500 & Oil Shares \\
\hline 1978 & 4.6 & 1.1 & 15.7 \\
1979 & 39.6 & 12.3 & 44.9 \\
1980 & 73.6 & 25.8 & -4.4 \\
1981 & 47.2 & -9.7 & -24.7 \\
\hline \hline
\end{tabular}

All variables are percentage changes. Share prices are year-end, from Compustat. Well-head oil price from Twentieth Century Petroleum Statistics 1993.

\section{Oil Share Performance, 1977-1981}

We compare the share price performance of seven US-based nondiversified oil companies to the growth rate of the S\&P 500 Composite Index and the nominal oil price. The firms are Pennzoil, Sun, Total Petroleum, Phillips Petroleum, Atlantic Richfield, Shland and Amerada Hess.

\section{References}

1. Achio Tacson, Mayra and Escalante, Ana C., Azucar y Politica en Costa Rica, Editorial Costa Rica, 1985.

2. Adelman, Morris A., "The Clumsy Cartel", The Energy Journal, 1980.

3. Alesina, Alberto and Perotti, Roberto, "The Welfare State and Competitiveness", mimeo, 1994.

4. Alexander, Robert, The Tragedy of Chile, Greenwood Press, 1978.

5. Bangura, Yusuf, "The Politics of Nigeria's Debt Crisis", in Nigerian Alternatives (ed. Oculi, O.), Ahmabu Ballo University, 1987.

6. Blanchard, Olivier, Florencio Lopez de Silanes and Andrei Shleifer, "What Do Firms Do With Cash Windfalls?", Journal of Financial Economics, forthcoming.

7. Booth, Anne (ed.), The Oil Boom and After: Indonesian Economic Policy and Performance in the Soeharto Era, Oxford University Press, 1992. 
8. Bresnan, John, Managing Indonesia: The Modern Political Economy, Columbia University Press, 1993.

9. Cohen, D. and Sachs, J., “Growth and External Debt Under Risk Of Debt Repudiation $^{n}$, European Economic Review 30, 529-60, 1986. 1986.

10. Connolly, Michael, Macroeconomic Policies, Crises, and Long-Run Growth in Cameroon, 1991.

11. Cooper, Richard, "Terms of Trade Shocks and Macroeconomic Management", manuscript, 1993.

12. Corden, W. Max and Neary, J. Peter, "Booming Sector and DeIndustrialisation in a Small Open Economy", Economic Journal, 825-48, 1982.

13. Cordova, Arnaldo, La Formacion del Poder Politico en Mexico, Ed. Era, 1972.

14. Cosio Villegas, Daniel, El Estilo Personal de Gobernar, Joaquin Mortiz Ed., 1975.

15. Dala Resources Inc., Review of the US Economy, Spring 1978.

16. Devarajan, Shantayanan, and De Melo Jaime, “Adjustment with a Fixed Exchange Rate: Cameroon, Cote d'Ivoire and Senegal", World Bank Economic Review 1, 447487,1987 .

17. Dornbusch, Rudiger, "Real Interest Rates, Home Goods, and External Borrowing", Journal of Political Economy 91, 141-151, 1983.

18. Eaton, J., "Sovereign Debt: A Primer", World Bank Economic Review, 137-72, 1993.

19. Floyd, Robert H., Clive S. Gray and R.P. Short, Public Enterprise in Mixed Economies: Some Macroeconomic Aspects, International Monetary Fund, 1984.

20. Ffrench-Davis, Ricardo, Politicos Economicas en Chile, Ediciones Nueva Universidad, 1973.

21. Gavin, Michael, "Adjusting to a Terms of Trade Shock: Nigeria, 1972-88", in Policymaking in the Open Economy: Concepts and Case Studies in Economic Performance (ed. Dornbusch, R.), EDI Series in Economic Development, 1993.

22. Gelb, Alan, Oil Booms: Windfall or Curse?, Oxford University Press, 1988. 
23. Glick, Reuven and Rogoff, Kenneth, "Global versus Country-Specific Productivity Shocks and the Current Account", NBER Working Paper \# 4140, 1992.

24. Gonzalez-Vega, C. and Cespedes, C., Ch 5, in The Political Economy of Poverty, Equity, and Growth:Costa Rica and Uruguay (ed. Rothenberg, S.), Oxford University Press, 1993.

25. Jacobstein, Helen, The Process of Economic Development in Costa Rica 1948-70, Garland, 1987.

26. Kaufman, Daniel, "The Forgotten Rationale for Policy Reform: The Productivity of Investment Projects", presented at the NBER Growth Conference, October 1991.

27. Le Vine, Victor, "Leadership and Regime Changes in Perspective", in The Political Economy of Cameroon(eds. Schatzberg, M. and Zartman, W.), Praeger Publishing, 1986.

28. Levy, Margaret, Of Rule and Revenue, University of California Press, 1988.

29. Little, lan, Richard Cooper, W. Max Corden, and Sarath Rajapatirana, Booms, Crisis and Adjustment: The Macroeconomic Experience of Developing Countries, Oxford University Press, 1993.

30. Maskin, Eric and Jean Tirole, " A Theory of Dynamic Oligopoly, I," Econometrica 56, 549-569, 1988.

31. Matsuyama. Kiminori, "Current Account Dynamics in a Finite Horizon Model", Journal of International Economics 23, 299-313, 1987.

32. Mehlman, Alexander, Applied Differential Games, Plenum Press, 1988.

33. Murphy, Kathleen, Macroproject Development in the Third World, Westview Press, 1983.

34. Mendez, Juan Carlos, Chilean Socioeconomic Overview, 1980.

35. Montenegro, Santiago, "The Legacy of the Oil Boom and Policy Options for External Debt Management ${ }^{n}$, unpublished, 1993.

36. Neary, J. Peter, and S. van Wijnbergen, Natural Resources and the Macroeconomy, MIT Press, 1986. 
37. Obstfeld, Maurice, "Aggregate Spending and the Terms of Trade: Is there a LaurenMetzler Effect?” Quarterly Journal of Economics 97, 251-270, 1982.

38. Obstfeld, Maurice and Rogoff, Kenneth, "The Intertemporal Approach to the Current Account ${ }^{n}$, manuscript, 1994.

39. Perotti, Roberto, "A NonConsumption-Smoothing Model of the Current Account", unpublished paper, 1993.

40. Pinto, Brian, "Nigeria: During and After the Oil Boom: A Policy Comparison with Indonesia", World Bank Economic Review 1, 419-445, 1987.

41. Razin, Assaf, "The Dynamic-Optimisation Approach to the Current Account" NBER Working Paper \#4334, 1993.

42. Royko, Michael, Boss: Richand Daley of Chicago, E. P. Dutton, 1971.

43. Sachs, Jeffrey, "The Current Account in the Macroeconomic Adjustment Process", Scandinavian Journal of Economics 84, 147-159, 1982.

44. Shleifer, Andrei and Vishny, Robert, "Politicians and Firms", Quarterly Journal of Economics, forthcoming.

45. Svensson, Lars and Assaf Razin, "The Terms of Trade and the Current Account : The Harberger-Laursen-Metzler Effect", Journal of Political Economy 91, 97-125, 1983.

46. Tornell, Aaron, "Are Crises Necessary for Trade Liberalization and Fiscal Reform: The Mexican Case, forthcoming in Stabilization, Economic Reform and Growth (eds. Dornbusch R., and Edwards, S.), University of Chicago Press, 1994.

47. Ukpong, Ignatius, Notes on the Nigerian Fiscal System, Ododuma \& Co., 1986.

48. Velasco, Andres, "The State and Economic Policy: Chile 1952-70", in The Chilean Economy: Policy Lessons and Challenges (eds. Bosworth, B., R. Dornbusch and R. Laban), Brookings Institution, 1993.

49. Widner, Jennifer, "Single Party States and Agricultural Policies: The Cases of Ivory Coast and Kenya", Contemporary Politics, 127-49, 1994.

50. Zartman, William and Delgado, Christopher (eds.), The Political Economy of Cameroon, Praeger Publishers, 1984. 